\title{
THE HOVERFLIES OF AN OAK DEHESA FROM SPAIN, WITH A NEW SPECIES AND OTHER INSIGHTS INTO THE TAXONOMY OF THE EUMERUS TRICOLOR GROUP (DIPTERA: SYRPHIDAE)
}

\author{
Antonio Ricarte ${ }^{1 *}$, Anita Nencioni ${ }^{1}$, NATAŠA KočIŠ TubiĆ ${ }^{2}$, \\ Ana Grković ${ }^{2}$, Ante VuJić ${ }^{2}$, M. Ángeles Marcos-García ${ }^{1}$ \\ ${ }^{1}$ Centro Iberoamericano de la Biodiversidad (CIBIO), Universidad de Alicante, \\ Carretera San Vicente del Raspeig s/n, 03690 San Vicente del Raspeig, Alicante, \\ Spain; e-mails: ricarte24@gmail.com,anita.nencioni@studio.unibo.it, \\ marcos@ua.es \\ ${ }^{2}$ University of Novi Sad, Faculty of Sciences, Department of Biology and Ecology, \\ Trg Dositeja Obradovića 2, 21000 Novi Sad, Serbia; e-mails: \\ natasa.kocis@dbe.uns.ac.rs,ana.grkovic@dbe.uns.ac.rs,ante.vujic@dbe.uns.ac.rs \\ "Corresponding author
}

\begin{abstract}
Dehesas are typical Mediterranean habitats for extensive livestock raising. Hoverflies (Diptera: Syrphidae) may act as bioindicators in dehesas, but they are still poorly known in this habitat type. With the purpose of the present study, hoverfly diversity was surveyed in Campanarios de Azaba, a typical oak dehesa in Salamanca province, Spain. A total of 41 species were recorded, including Eumerus azabense sp. nov. This new species was found to belong to the Eumerus tricolor group, both in morphological and genetic terms, and clearly separated (DNA characters) from the similar Eumerus niveitibia, which is redescribed here. Genetic monophyly of the E. tricolor group is confirmed in the present paper. An updated hoverfly checklist of Salamanca province is provided (152 sp.) with indication of the 56 species recorded in Campanarios de Azaba. Obtained results address the importance of dehesa biodiversity, which includes species new to science.
\end{abstract}

\section{$\mathscr{8}$}

Key words.- Iberian Peninsula, Salamanca, Quercus, Eumerus azabense sp. nov., Eumerus niveitibia, neotype, COI barcodes, bioindication.

\section{INTRODUCTION}

With a long history of human use, the Mediterranean Basin is one of 35 biodiversity hotspots on Earth (Myers et al. 2000, Mittermeier et al. 2011, Williams et al. 2011). The entire Iberian Peninsula except for some northern and north-western parts is included in this hotspot (Marchese 2015). This southern region of Europe has typical Mediterranean habitats such as the dehesa, which covers an extension of 3.5-4.0 million ha, mainly in the south-west of Spain (Olea and San Miguel-Ayaz 2006). Dehesa is an agrosilvopastoral system for extensive livestock raising (Olea and San Miguel-Ayaz, 2006) and originates from clearance and brushwood removal of the native Mediterranean forest (Ramírez-Hernández et al. 2014). The dehesa landscape has a characteristic savannah-like appearance with oaks of different species, Quercus 
spp, according to the region (Campos et al. 2013, Ramírez-Hernández et al. 2014, 2015a). Dehesas are considered to be important both in ecological and socioeconomic terms (e.g. Bugalho et al. 2011, Marañón, 1991, Galante et al. 1991, Ramírez-Hernández et al. 2014), they are included in the 92/43/EEC Habitat Directive and the Nature 2000 Network (Olea and San Miguel-Ayaz 2006).

Some insect groups such as the hoverflies (Diptera: Syrphidae) might be used as bioindicators in productive systems (e.g. Sommaggio 1999, Sommaggio and Burgio 2014). However, knowledge of the dehesa hoverflies is insufficient for them to be used as bioindicators. Apart from the data on a few - mainly saproxylic species from the Spanish provinces of Salamanca and Huelva (Marcos-García 1985, Ramírez-Hernández et al. 2014, Ricarte et al. 2016, Ricarte and MarcosGarcía 2017), hoverfly communities of dehesas are virtually unknown. Although hoverflies are well studied at the European level (Rotheray and Gilbert 2011, Speight 2015), regional faunas are still poorly understood, mainly those of southern Europe (Petanidou et $a l .2011$, Ricarte et al. 2014). New species of frequently-recorded Mediterranean genera still await discovery, as the recent description of new Eumerus species from Greece suggests (Ricarte et al. 2012, Grković et al. 2015).

Taxonomy provides the basic tools to understand alpha biodiversity of ecosystems. However, traditional taxonomy, based on morphological characters, is experiencing a substantial change by incorporation of new kinds of characters for species separation; for example, molecular, geometric morphometric and ecological characters (e.g. Haarto and Ståhls 2014, Nedeljković et al. 2015). DNA barcoding of taxa is becoming a routine practice in taxonomic studies, with the purpose of building reference DNA-sequence libraries for subsequent species identification (Kress et al. 2015).

The main aim of the present study is to better understand the hoverfly community of a typical dehesa from the Iberian Peninsula, as well as to contribute to knowledge of the taxonomy of the Eumerus tricolor group, which is represented in this habitat by a species new to science.

\section{MATERIAL AND METHODS}

Study area. The hoverfly survey took place in the Biological Reserve of 'Campanarios de Azaba' (Fig. 1), a typical dehesa found in Salamanca, western Spain (40 29.769 N $647.551 \mathrm{~W})$. This reserve has an extension of $522 \mathrm{ha}$. The altitude is $800 \mathrm{~m}$. The climate is typical Continental. The average annual temperature is over $12^{\circ} \mathrm{C}$. The average annual precipitation is less than $800 \mathrm{~mm}$. Dominant tree species are $Q$. rotundifolia and Q. pyrenaica. Tree density is 39 trees/ ha. Campanarios de Azaba is managed by the 'Naturaleza

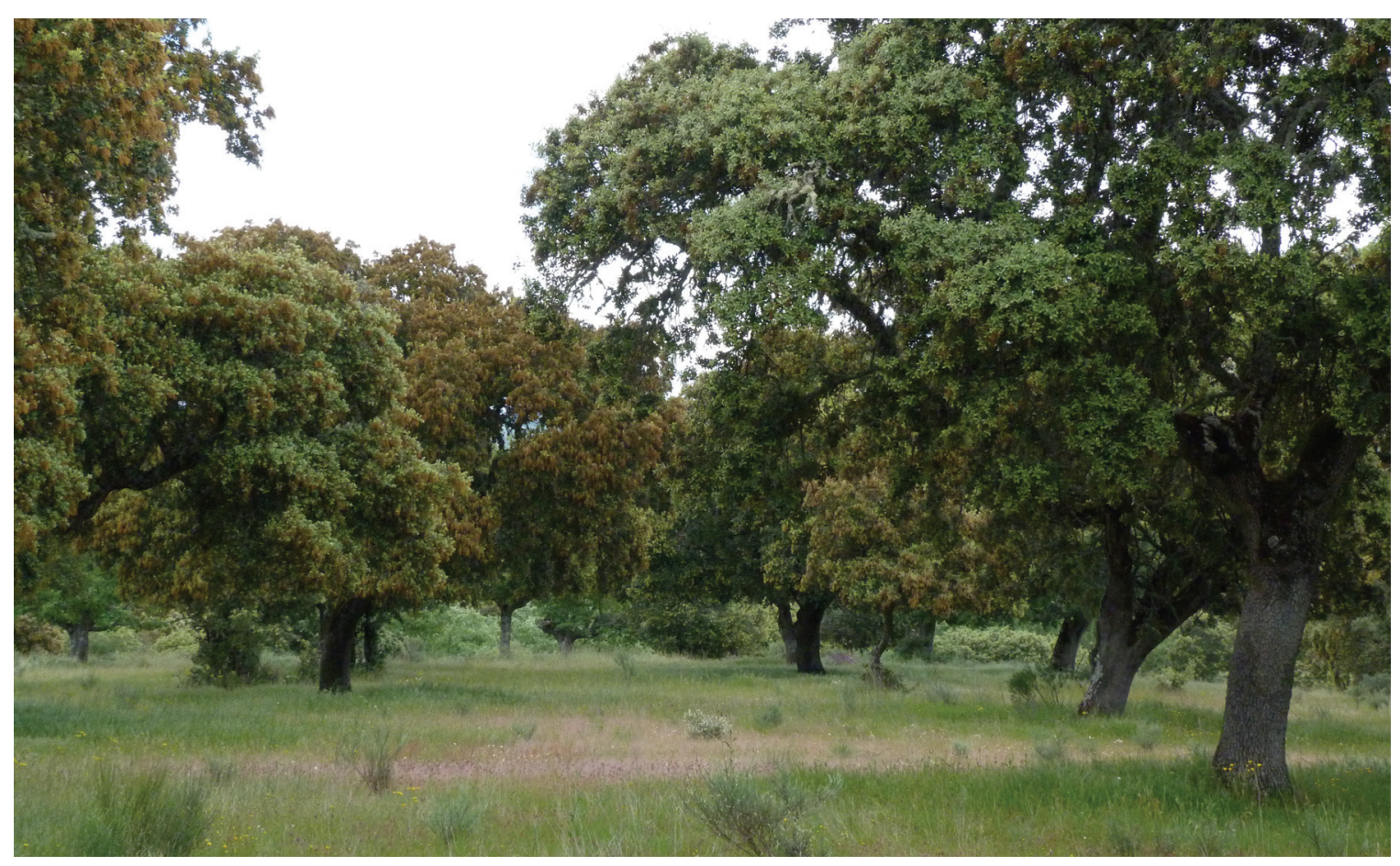

Figure 1. Campanarios de Azaba, Salamanca, Spain. A typical oak dehesa. 
y Hombre' Foundation (http://fnyh.org/la-fundacion/) under sustainable practices of pasture grazing and tree pruning (Sánchez-Martínez et al. 2012). This area is included in the Natura 2000 Network and is catalogued as 'Reserva Entomológica' (Entomological Reserve) by the Asociación Española de Entomología (http://www.entomologica.es/).

Sampling protocol. Hoverflies were collected with Malaise traps, from May to November 2010 and from January to November 2011. Catcher pots contained ethanol $70^{\circ}$ as preservative liquid and ethylene-glycol as anti-freezing. Samples were collected every 30 days; from June to September samples were collected every 15 days due to temperature provoking higher alcohol evaporation. Dehesa was divided into different vegetation units according to the $\%$ of scrub cover: unit 'P1', with 5-25\% of scrub cover (low cover); units 'P19' and 'P20', with $30-90 \%$ of scrub cover (moderate to high cover). Four Malaise traps were used to collect insects, two (MT1, MT2) in the unit P1, one (MT19) in the unit P19 and other (MT20) in the unit P20 (Table 1). A small part of the examined material was collected with Emergence Traps ('ET'), Window Traps ('WT') and Beer Traps ('T-Cerveza') used by Ramírez-Hernández et al. (2014).

Morphological study. Hoverflies were identified using keys and descriptions in Bartsch et al. (2009a, 2009b), Claussen (1989), Gil-Collado (1930), Van Veen (2004), Violovitsh (1974), Vujić and Simić (1999), Ricarte et al. (2010), Marcos-García et al. (2007) and Goeldlin (1976). For species identification, male genitalia were dissected and prepared for study following Ricarte $e t a l$. (2012). Examined material was identified by Anita Nencioni, Antonio Ricarte and M. Ángeles Marcos-García, unless otherwise stated. Examined material is deposited at the Research Institute CIBIO, in the 'Colección Entomológica de la Universidad de Alicante' (CEUA). For examined material of Eumerus niveitibia Becker, 1921, repository collections are:
MAegean - The Melissotheque of the Aegean, University of the Aegean, Mytilene, Greece;

TAU - Zoölogisch Museum Amsterdam, Netherlands (ZMA); Tel Aviv University, Israel;

RMNH - Nationaal Natuurhistorisch Museum, Leiden, Netherlands.

For species descriptions, morphological terms follow Thompson (1999). Body length ('L') was measured from the tip of the frontal prominence (excluding antenna) to the tip of the abdomen. Wing length ('WL') was measured from the insertion point on the thorax to the tip of the wing. Measurements were made using an eyepiece micrometer. Species were illustrated either with photos or drawings. Photos were produced as stalks of individual images made with a camera (Leica DFC 450) attached to a binocular stereomicroscope (Leica M205 C). Stalks were made in Adobe Photoshop ${ }^{\circledR}$ v. 2015. Drawings were elaborated from photos made with a camera Leica DFC 320 attached to a binocular stereomicroscope Leica MZ16; hand-made drawings were processed in GNU Image Manipulation Program (GIMP) software. For the new species genitalia, the presented drawing was hand-made from a printed stalk of photos made with a camera (Leica DFC 450) attached to a binocular stereomicroscope (Leica M205 C). For each species, trophic habits of larvae and other relevant data are provided under 'Notes' following Speight (2015), unless otherwise stated.

Molecular study. COI barcodes were analysed from 18 Eumerus specimens, of which 10 represented the following species of the E. tricolor group sensu Chroni et al. (2017): Eumerus tricolor (1), Eumerus grandis (1), Eumerus armatus (1), Eumerus sinuatus (1), Eumerus aurofinis (1), Eumerus ovatus (1), Eumerus niveitibia (2) and Eumerus azabense sp. nov. (2) (Appendix 2). DNA voucher specimens were deposited in the following collections: CEUA, 'Colección Entomológica de la Universidad de Alicante', Spain; FSUNS, Faculty of Sciences, University of Novi

Table 1. Vegetation units in 'Campanarios de Azaba' dehesa, Salamanca, Spain. For each unit, the vegetation cover (\%) and dominant plant species/community are detailed.

\begin{tabular}{|l|l|l|l|l|}
\hline Malaise trap code & \multicolumn{1}{|c|}{ Woodland cover } & \multicolumn{1}{|c|}{ Scrubland cover } & \multicolumn{1}{c|}{ Grassland cover } & $\begin{array}{l}\text { Vegetation } \\
\text { unit code }\end{array}$ \\
\hline MT1, MT2 & $40 \%$, Q. rotundifolia & $\begin{array}{l}10 \%, \text { Lavandulo sampaianae, } \\
\text { Cytisetum multifloris }\end{array}$ & $\begin{array}{l}95 \%, \text { Stellarietea mediae; } \\
5 \%, \text { pasture }\end{array}$ & P1 \\
\hline MT19 & $\begin{array}{l}40 \%, \text { dehesa-like } \\
\text { Q. rotundifolia forest; } \\
10 \%, \text { marcescent oaks }\end{array}$ & $\begin{array}{l}90 \%, \text { Cytisus multiflorus } \\
40 \%, \text { Tubenarion guttatae }\end{array}$ & P19 \\
\hline MT20 & $\begin{array}{l}30 \%, \text { Q. rotundifolia with } \\
\text { deciduous trees }(20 \%)\end{array}$ & $\begin{array}{l}40 \%, \text { Lavandulo sampaianae } \\
\text { Cytisetum multifloris }\end{array}$ & $60 \%$, Tubenarion guttatae & P20 \\
\hline
\end{tabular}


Sad, Serbia; MAegean, The Melissotheque of the Aegean, University of the Aegean, Mytilene, Greece.

DNA was extracted from two to three legs of dry pinned specimens. Extractions were carried out using the slightly modified SDS Extraction Protocol (Chen et $a l ., 2010)$; samples were re-suspended in $30 \mu \mathrm{l}$ of $0.1 \mathrm{xTE}$ buffer for further analyses. The COI barcodes (5' region of the mitochondrial cytochrome $c$ oxidase subunit I gene) were amplified with forward primer LCO-1490 (5'-GGTCAACAAATCATAAAGATATTGG-3') and reverse primer HCO-2198 (5'-TAAACTTCAGGGTGACCAAAAAATCA-3') (Folmer et al. 1994). PCR reactions were carried out in $25 \mu \mathrm{l}$ reaction volumes and the reaction mix consisted of $1 \mathrm{xTaq}$ buffer (ThermoScientific, Lithuania), $2 \mathrm{mM} \mathrm{MgCl}_{2}, 0.1 \mathrm{mM}$ of each nucleotide, $1.25 \mathrm{U}$ Taq polymerase, $5 \mathrm{pmol}$ of each primer, and approximately $50 \mathrm{ng}$ DNA. Amplification was performed in an Applied Biosystems Verity thermal cycler under the following conditions: initial denaturation for 3 min at $94^{\circ} \mathrm{C} ; 30 \mathrm{~s}$ denaturation at $94^{\circ}, 45 \mathrm{~s}$ annealing at $50^{\circ} \mathrm{C}, 1 \mathrm{~min}$ extension at $72^{\circ} \mathrm{C}(29$ cycles $)$; and the final extension for $8 \mathrm{~min}$ at $72^{\circ} \mathrm{C}$. The PCR products were enzymatically treated with the Exonuclease I and Shrimp Alkaline Phosphatase enzymes (ThermoScientific, Lithuania) and then sequenced using the forward primer and ABI3730x1 Genetic Analyzer (Applied Biosystems) at the Finnish Institute for Molecular Medicine (FIMM), Helsinki, Finland (http://www.fimm.fi). The obtained sequences were submitted to GenBank (for accession numbers see Appendix 2).

For molecular data analysis, the COI barcode sequences were aligned using Clustal W (Thompson et al. 1994) as implemented in BioEdit version 7.2.5 (Hall 1999). A species of Archimicrodon Hull, 1945 (GenBank accession no. KU365483) and Xanthogramma citrofasciatum De Geer, 1776 (GenBank accession no. KU365484) were used as outgroups. The sequences were clustered using Maximum Likelihood (ML) analysis implemented in MEGA version 7.0.21 (Kumar et al., 2016) under the General Time Reversible model-GTR (Nei and Kumar 2000) and invariant rate among sites $(+\mathrm{I})$. Nodal support for the tree was assessed using non-parametric bootstrapping with 1000 replicates.

\section{Results}

\section{Taxonomy}

Eumerus azabense Ricarte \& Marcos-García sp. nov. Figs $2-5,6 \mathrm{~B}$

Examined material [CEUA]. Holotype: $1 \mathrm{~m}$, Campanarios de Azaba, Salamanca, Spain, Malaise 19, 6.v.2011, leg. Quinto, García and Ramírez (DNA analysis; genitalia without hypandrium apex and part of the sub-triangular structure of surstylus, stored in a plastic microvial).

Paratypes: $3 \mathrm{~m}$ and $2 \mathrm{f}$, Campanarios de Azaba, Salamanca, Spain, Malaise 2, 7.vi.2011 (3 m and $1 \mathrm{f} ; 1 \mathrm{~m}$ without the right metaleg and part of right mesoleg detached; $1 \mathrm{~m}$ with right metaleg detached), 9.vii.2011 (1 f, DNA analysis), leg. Quinto, García and Ramírez; $4 \mathrm{f}$, Campanarios de Azaba, Salamanca, Spain, Malaise 10 (2 f), Malaise 19 (1 f), Malaise 20 (1 f), 26.vi.2010, leg. Hernández and Briones.

Etymology. The epithet 'azabense' means 'from Azaba' and refers to the type locality of this species, Campanarios de Azaba.

Diagnosis. Large species (L, 8.9-12.5 mm; WL, $7-9.5 \mathrm{~mm}$; $\mathrm{n=10}$ ), black (Fig. 2) except for the female terga, which are red, at least laterally (Fig. 3); dorsal part of body with inconspicuous dark blue reflections, which might be more obvious under microscope light (Figs 2A, 3A); eye with dense and long pilosity (Fig. 4); eyes approximated along a very short line (Fig. 4A); basoflagellomere trapezoid, with striae and a concave ellipsoidal area apically (Fig. 5); scutum, scutellum, pleuron and legs black; scutum and scutellum with both light brown and black pile; metafemur moderately swollen, with a row of 7 spinae on the ventral surface apically; dorsal part of all tibiae covered in silvery white pile obscuring partly the background colour of the tibia (Fig. 2B, see protibia); cells $\mathrm{C}, \mathrm{R}, \mathrm{BM}$ and $\mathrm{CuP}$ dark brown pigmented; vein $\mathrm{R} 4+5$ moderately curved; terga II-IV with two white-pollinose maculae not reaching the lateral margins (Fig. 2A); terga with white to light brown pile, except for the black pile on the posterior margin of tergum II and central parts of terga III and IV (Fig. 2A); white pile of sterna I and II wavy at the apex; male genitalia similar to those in Eumerus niveitibia (Fig. 6).

Description - Male (holotype). $\mathrm{L}=10.9 \mathrm{~mm}, \mathrm{WL}=$ $9 \mathrm{~mm}$. Head (Fig. 4). Eye densely pilose, except for the bare posterior margin; eye pile light brown, long, slightly shorter on the lower and upper part of eye; eye facets near the eye contiguity $2 \times$ larger than those in the lower part of eye; vertical triangle and occiput black; ocellar triangle isosceles; vertical triangle with long erect black pile and, on the area posterior to the ocellar triangle, light brown pile intermixed; eyes approximated along a very short line, which is as wide as one of the closest eye facets; frontal triangle and face shiny, just sparsely pollinose, and with light brown pile; scape and pedicel black; pedicel with light brown pile, except for some black pile dorsally; basoflagellomere trapezoid, black (reddish black in a male paratype), grey pollinose, with striae; outer surface of the basoflagellomere apex with a concave ellipsoidal area; antennal arista black, basally thickened. Thorax (Fig. 2). Scutum, scutellum, pleuron and legs black, except for some reddish areas of the pleuron posteriorly and 

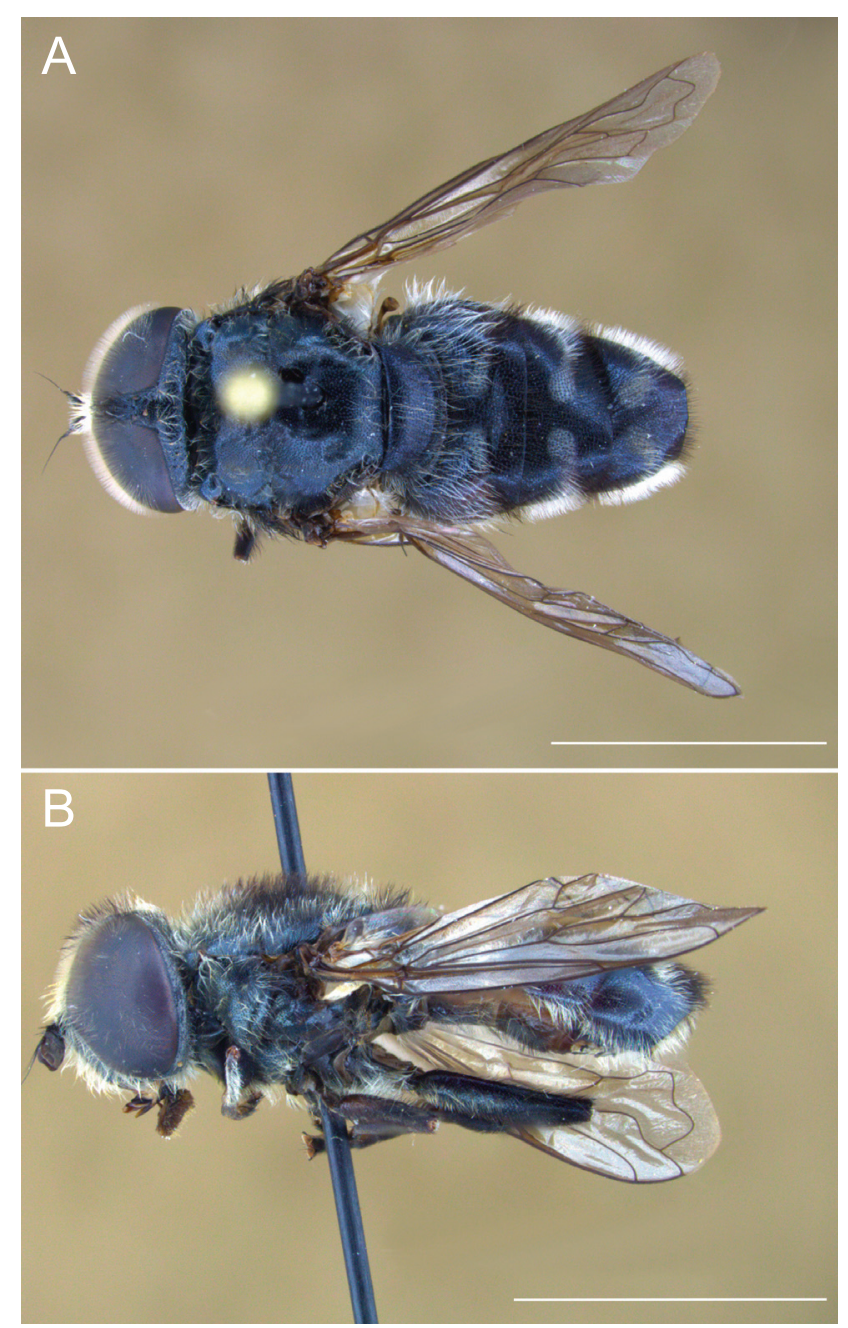

Figure 2. Eumerus azabense sp. nov., male holotype, overall appearance: (A) dorsal view; (B) lateral view. Scale bars $=5 \mathrm{~mm}$.

a reddish macula on the mesofemur (all these parts completely black in the male paratypes); scutum and scutellum with long light brown pile and, on the notopleuron, posterior part of scutum, area above wing base, postalar callus and all over the scutellum, black pile intermixed; scutum and scutellum shiny black, sparsely punctate, with large punctures; pleuron pollinose, except for the shiny dorsal part of anepimeron, postero-dorsal part of anterior anepisternum and posterior part of posterior anepisternum; all femora with both black and white to light brown pile; metafemur moderately swollen, in its apical part with a row of 7 spinae on the anterior ridge of the ventral surface and a row of 5 spinae on the posterior ridge (most spinae of the posterior ridge are smaller and more closely arranged than those on the anterior ridge); dorsal part of all tibiae covered in semi-adpressed silvery-white pile in such a way that the background colour of the tibia is almost obscured by these white pile, if tibia seen in baso-dorsal view; wing microtrichose except for some bare areas in cells R, BM, CuP and alula; cells C, R, BM and $\mathrm{CuP}$ slightly pigmented (pigmentation is darker in the male paratypes); veins extensively black; vein R4+5 moderately curved; calypter light yellow; halter with whitish pedicel and blackish capitulum basally. Abdomen (Fig. 2). Terga II-IV with two white-pollinose maculae not reaching the lateral margins of terga; pollinose maculae of tergum II nearly parallel to the posterior margin of the tergum; pollinose maculae of terga III and IV expanded at their inner end, arranged in a more diagonal position than those in tergum II; terga II-IV extensively black; tergum II with a triangular red macula on the lateral margin; tergum III reddish laterally, including the outer half of the pollinose macula; lateral margin of tergum IV faintly reddish (in some paratypes, entire tergum IV virtually black); terga with white to light brown pile, except for the black
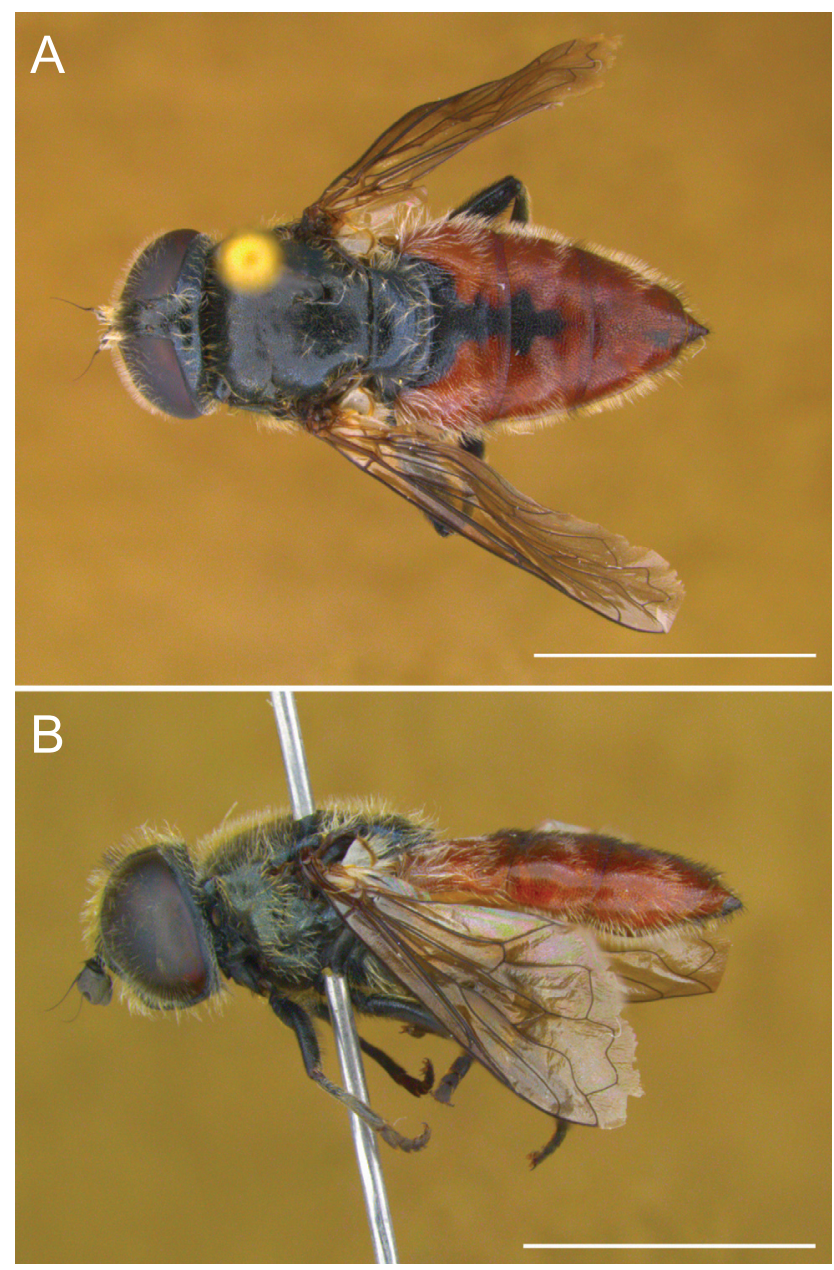

Figure 3. Eumerus azabense sp. nov., female paratype, overall appearance: (A) dorsal view; (B) lateral view. Scale bars $=5 \mathrm{~mm}$. 

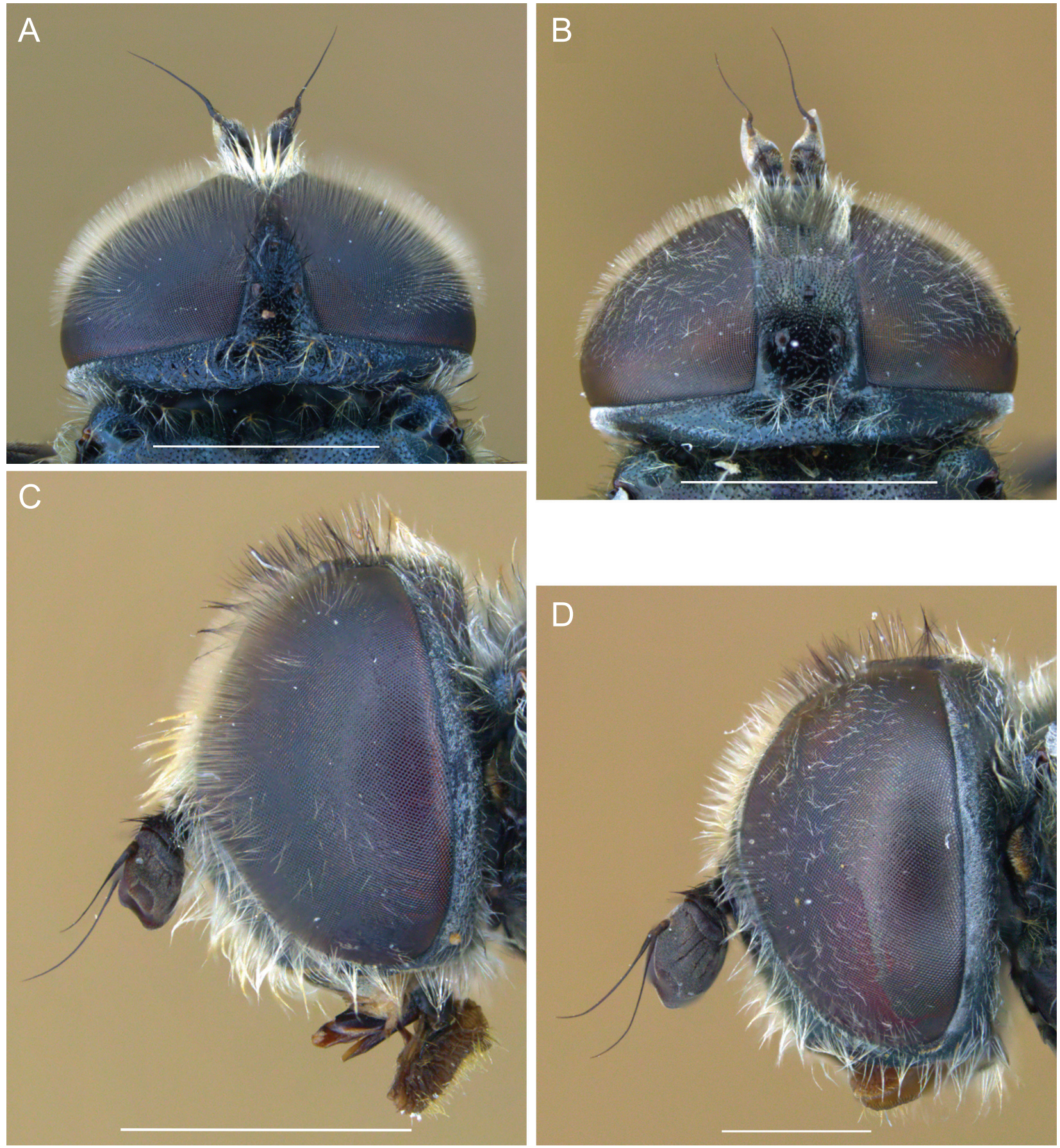

Figure 4. Eumerus azabense sp. nov., head: (A) male holotype, dorsal view; (B) female paratype, dorsal view; (C) male holotype, lateral view; (D) female paratype, lateral view. Scale bars $=2 \mathrm{~mm}$ (A, B, C), $1 \mathrm{~mm}$ (D).

pile on the posterior margin of tergum II and central parts of terga III and IV; lateral margins of terga II-IV with longer white pile, intermixed with black pile at the posterior corner of terga II and III and at the anterior corner of terga III and IV (black pile are variable in number according to the examined specimen); sterna I-IV reddish black, but sterna I and IV darker; sterna
I-III with long white pile and, on the posterior margin, from just a few to some black pile intermixed; white pile of sterna I and II wavy at the apex. Genitalia (Fig. 6 ). Base of hypandrium with an elongate flat transversally-striated lingula extending for about a third of the hypandrium length; in lateral view, posterior lobe of the surstylus consisting of a sub-triangular piece 
bearing setulae (near the cercus) and a globular piece sinuous and densely setulose in the inner surface (setulae very short and not sclerotised) and with a notch in the outer surface.

Female. L, 8.9-12.5 mm; WL, 7-9.5 mm ( $\mathrm{n=6}$ ). Same as male except for the following characters: frons shiny black, with light brown pile only (Fig. 4B); frons nearly as wide as metafemur; basoflagellomere black to dark brown (Fig. 5); black pile of scutum and scutellum sparser than in male; terga II-IV red (Fig. 3); between the pollinose maculae, terga II and III with a medial black vitta from the anterior to posterior margin, in tergum III sometimes not reaching the posterior margin (Fig. 3A); tergum IV from extensively red to having a black medial vitta never reaching the posterior margin of tergum; white pilosity of terga more extensive than that in male; sternum I black, sometimes with red to reddish black posterior margin; sterna II and III red to reddish black (when sternum III red, then its posterior margin reddish black) and sternum IV reddish black.

Taxonomic notes. This species belongs to the E. tricolor group due to the following characters: large body size (8-12 mm); body extensively black (Figs 2, 7), usually with red markings on tergites (Fig. 3); squareshaped basoflagellomere, with striae (Fig. 5, 8C, D); male genitalia with poorly developed anterior surstylar lobe (Fig. 6AC); posterior surstylar lobe with a densely-setulose interior accessory lobe (Fig. 6B). Accepting that the 'terga II and III have large red areas laterally' (step 11 of key), the studied males of E. azabense sp. nov. would key out as Eumerus ovatus Loew using Stackelberg (1961). However, male of E. ovatus can be readily separated from that of $E$. azabense sp. nov. by the pilosity of the central plate of terga III and IV,

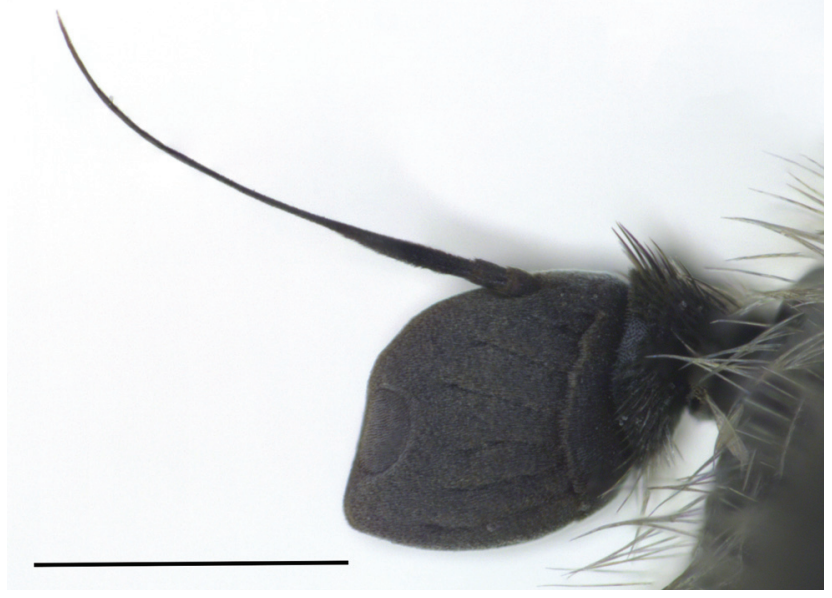

Figure 5. Eumerus azabense sp. nov., antenna, female paratype. Scale bar $=0.5 \mathrm{~mm}$. which is black and sparse in E. azabense sp. nov. (Fig. 2A), but silvery white and dense in E. ovatus [see Dussaix (2010)]. E. azabense sp. nov. is similar to Eumerus niveitibia Becker (see under Redescritpion of E. niveitibia), but they can be separated by the following characters: in E. azabense sp. nov., dorsal part of body has very inconspicuous dark-blue reflections (Fig. 2A); terga red, at least laterally (Figs 2A, 3); central plate of tergum IV (including pollinose maculae) extensively black pilose (Fig. 2A); in E. niveitibia, dorsal part of body has conspicuous blue reflections (Fig. 7); terga extensively black (Fig. 7); central plate of tergum IV (including pollinose maculae) extensively white pilose, especially in male (Fig. 7A). Differences found in the male genitalia of $E$. azabense sp. nov. and E. niveitibia were regarded as not diagnostic based on the available material (Fig. 6).

Range. Spain (Salamanca province).

\section{Eumerus niveitibia Becker, 1921}

Figs. 6A, C, D, 7-9

Note. This species was described from a single male collected in mainland Greece, apparently in the mountain Parnassus ('Parnafs'). According to Pape \& Thompson (2013), the holotype is deposited in the Museum für Naturkunde, Berlin, Germany. However, this holotype was lost in Becker's time (Joachim Ziegler in lit.) and here we designate a neotype. The taxonomic identities accepted in the present publication were established based on the descriptions of Becker (1921), Sack (1932) and Stackelberg (1961). Unique characters on the metatibia, the characteristic coloration of the body pile, as well as pile on the eyes and face undoubtly indicate species affiliations. To firmly associate the name $E$. niveitibia with a species concept, we designate here a male neotype. Due to high level of endemism in the hoverflies on the Greek islands (Ricarte et al. 2012, Grković et al. 2015, 2017, Chroni et $a l$. in prep.), we designate as neotype a male from Bulgaria, which we consider to be conspecific with the missing holotype collected in mainland Greece.

Examined material. Neotype (designated here): $1 \mathrm{~m}$, Nessebar, Bulgaria, 21.vii.2009, leg. A. Barendregt [RMNH]; Other records: 1 m, Eressos, Lesvos, Greece, 20.v.2004, leg. Messinger [MAegean]; $1 \mathrm{f}$, Parori, Peloponnese, Greece, 30.v.1995, leg. G. den Hollander [ZMA]; 1 m, Gebel Katharina, Sinai, Egypt, 25.vi.1998, leg. A. Freidberg \& F. Kaplan [TAU].

Diagnosis. Large species (L, 10-12 mm; WL, 7-9 $\mathrm{mm}$ ) with blue reflections (Fig. 7). Eye with long, pale and dense pilosity (Fig. 8); eye contiguity about 10 facets long; antenna with basoflagellomere striated and, apically, with a flattened ellipsoidal area, which in the female is remarkably enlarged (Figs 8C, D); unlike 

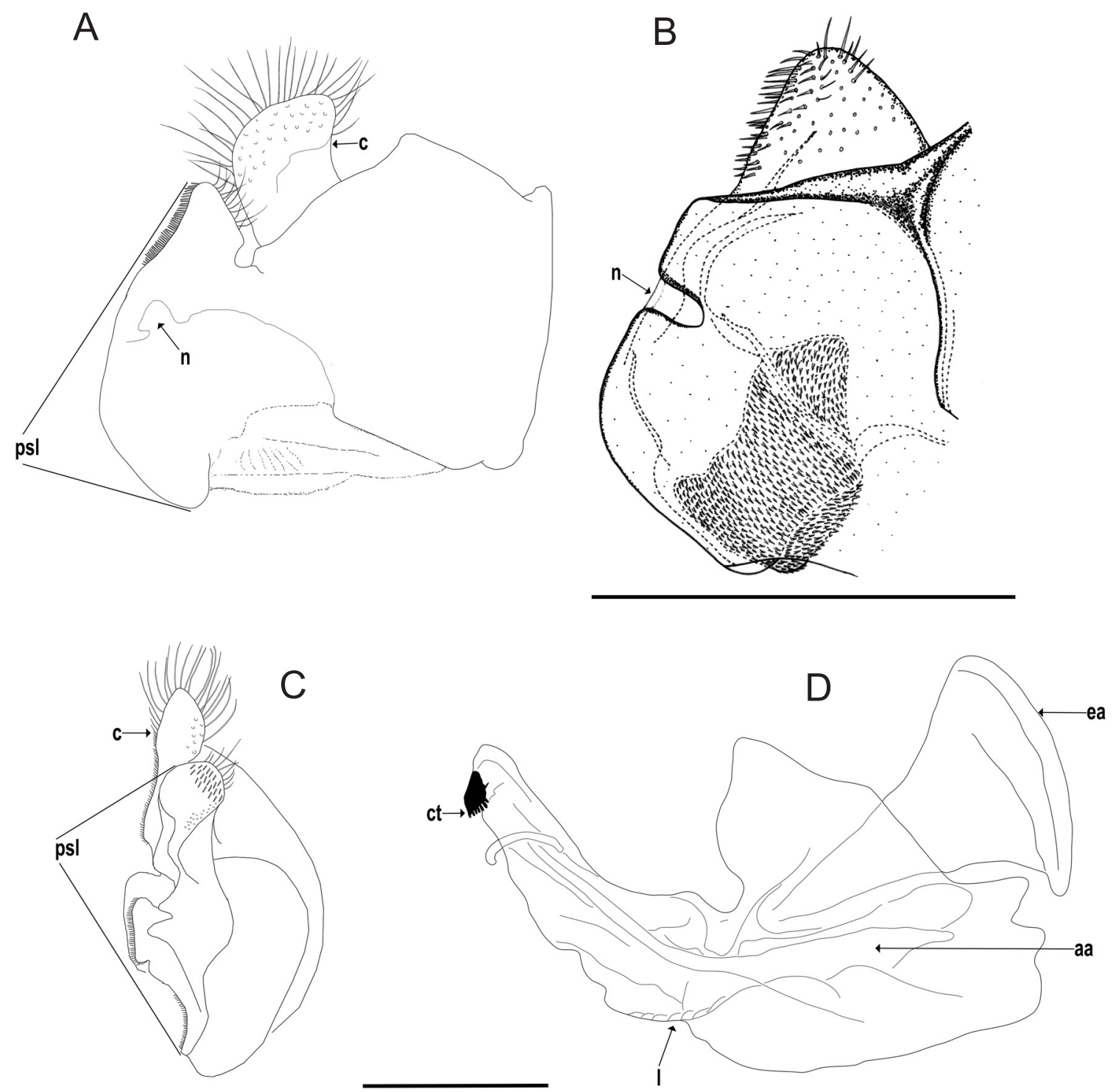

Figure 6. Eumerus niveitibia Becker, 1921 (specimen from Lesvos island) and Eumerus azabense sp. nov. (paratype), male genitalia: (A) epandrium of E. niveitibia, lateral view; (B) surstylus of E. azabense sp. nov. showing detail of the outer-side and inner-side structures, lateral view; (C) epandrium of E. niveitibia, anterior view; (D) hypandrium of E. niveitibia, lateral view. The anterior surstylar lobe is very poorly developed and then not indicated in the figure A-C. Legend: aa, aedeagal apodeme; c, cercus; ct, ctenidia; ea, ejaculatory apodeme; l, lingula; $\mathrm{n}$, notch; psl, posterior surstylar lobe. Scale bars $=0.5 \mathrm{~mm}$ (upper bar applies to B; lower bar applies to A, C and D).

most species of the E. tricolor group, in male, terga are black (Fig. 7), just occasionally with faintly visible red maculae on lateral margins of terga II-IV and translucent distal margin of tergum IV; in male, body pilosity predominantly black on head and thorax, but white on abdominal terga (Fig. 7); in female and sometimes in male, pilosity predominantly white all over the body, except for the black-pilose terga. Legs black, ventrally with black pile and conspicuous silvery-white pile dorsally (Fig. 7B).
Redescription of male. Head (Figs 7, 8). Eye contiguity about 10 facets long; eye densely pilose with bare posterior margin; eye with long pale pile, which are about a third shorter in the lower and posterior parts of eye; vertical triangle and occiput black with blue reflections; ocellar triangle isosceles; the distance between the anterior ocellus and a posterior ocellus is twice longer than the distance between posterior ocelli; distance between a posterior ocellus and eye margin small, same as half the diameter of an individual 
ocellus; face and vertical triangle with long, black, dense pilosity; pile on mouth margin lighter; scape and pedicel brown; dorsal pile of pedicel long (as long as the pedicel depth) and black; ventral pile of pedicel pale, as long as the dorsal pile, with a few longer black pile intermixed; basoflagellomere dark brown, slightly axe-shaped, grey to golden pollinose; outer side of basoflagellomere with up to five radially-arranged striae and a concave ellipsoidal area on distal margin;

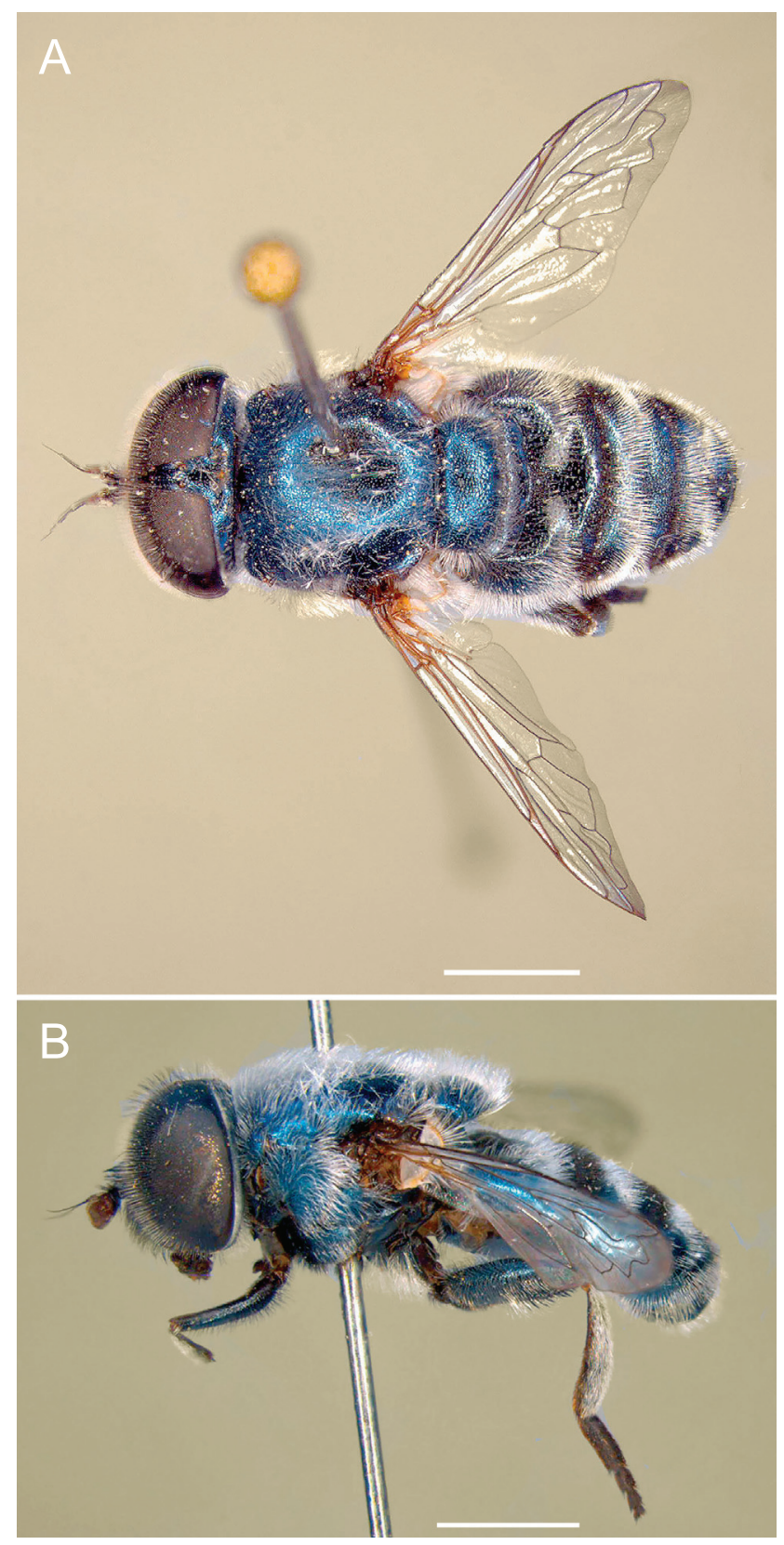

Figure 7. Eumerus niveitibia Becker, 1921, male neotype, overall appearance: (A) dorsal view; (B) lateral view. Scale bars $=2 \mathrm{~mm}$. arista dark brown, thickened basally. Thorax (Fig. 7). Scutum, scutellum and pleuron black, shiny, gently punctured, with more or less conspicuous blue reflection; scutum and pleuron with long, dense pile; pleural pile slightly wavy apically; pile on scutellum pale brown to white; katatergum with short, brown pile; mesofemur postero-laterally with a fringe of long, grey to white pile; metacoxa with very long white pile anteroventrally; metatrochanter with short black pile; metafemur slightly swollen, with pile of about the same length all over, pale brown to white dorsally and laterally, but black ventrally; apical part of metafemur with a row of 9-10 thorn-like spinae on the anterior ridge of the ventral surface (Fig. 9A) and a row of 8-9 thorn-like spinae on the posterior ridge; dorsal part of all tibiae covered in a conspicuous, long, silvery-white pilosity; wing transparent, entirely sparsely microtrichose; vein R4+5 moderately curved; halter light brown; calypter white. Abdomen (Fig. 7, 9C). Terga black with blue reflections; lateral margins of terga II-IV sometimes with faintly visible red maculae and the distal third of tergum IV translucent; tergum I covered in short black pile; terga II-IV covered in long white dense pilosity, which provides a velvet appearance to the abdomen; terga II and III posteriorly with shorter black pile; tergum IV with a few black pile only on anterior margin; each of terga II-IV with a pair of white pollinose maculae, which reach lateral margins only on tergum III; maculae on tergite II narrower, parallel to posterior margin of tergum; maculae on terga III and IV curved, wider at their inner ends; sternum I black; sterna II-IV yellowish to reddish black; sternum IV with blue reflections; sternum I with long yellowish to white pile and brown pile intermixed; sternum II with yellowish to white pile, slightly longer than those on sterna I and III-IV; sterna III and IV with long brown pile. Genitalia (Fig. 6). Base of hypandrium with an elongate transversally-striated lingula, rope-shaped in appearance in its outer side in lateral view; aedeagal apodeme with a dorsal process and, laterally, curved down; ejaculatory apodeme with very strong and expanded edge; subapical ctenidia; posterior surstylar lobe as in E. azabense sp. nov.

Description of female. Same as male except for the following characters: ocellar triangle slightly longer than wide (Fig. 8B); face, frons and occiput with long white pile, except for the black pile on the ocellar triangle; frons narrower than metafemur; white pollinosity along dorsal eye corner (Fig. 8D); basoflagellomere large, wrinkled, reddish brown (Fig. 8D); scutum, anepisternum and katepisternum white pilose with a few black pile intermixed; scutum with a row of black setae just above wing insertion; postalar callus with distinctive black and white pile intermixed; anepimeron covered in black pile; metatrochanter with white pile; all pile on metafemur of about the same length; 
A

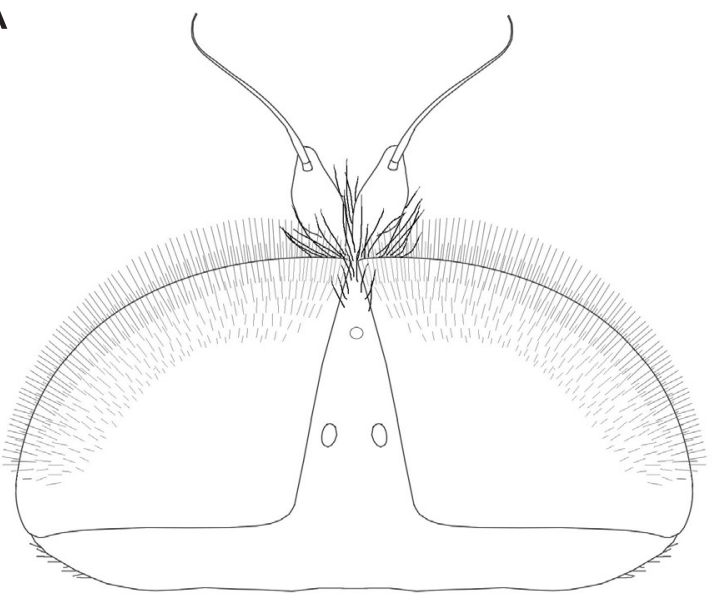

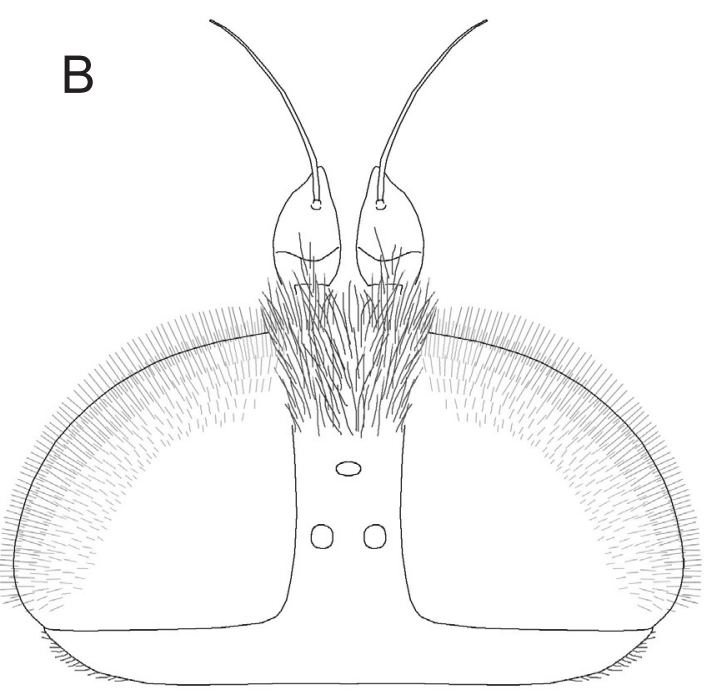
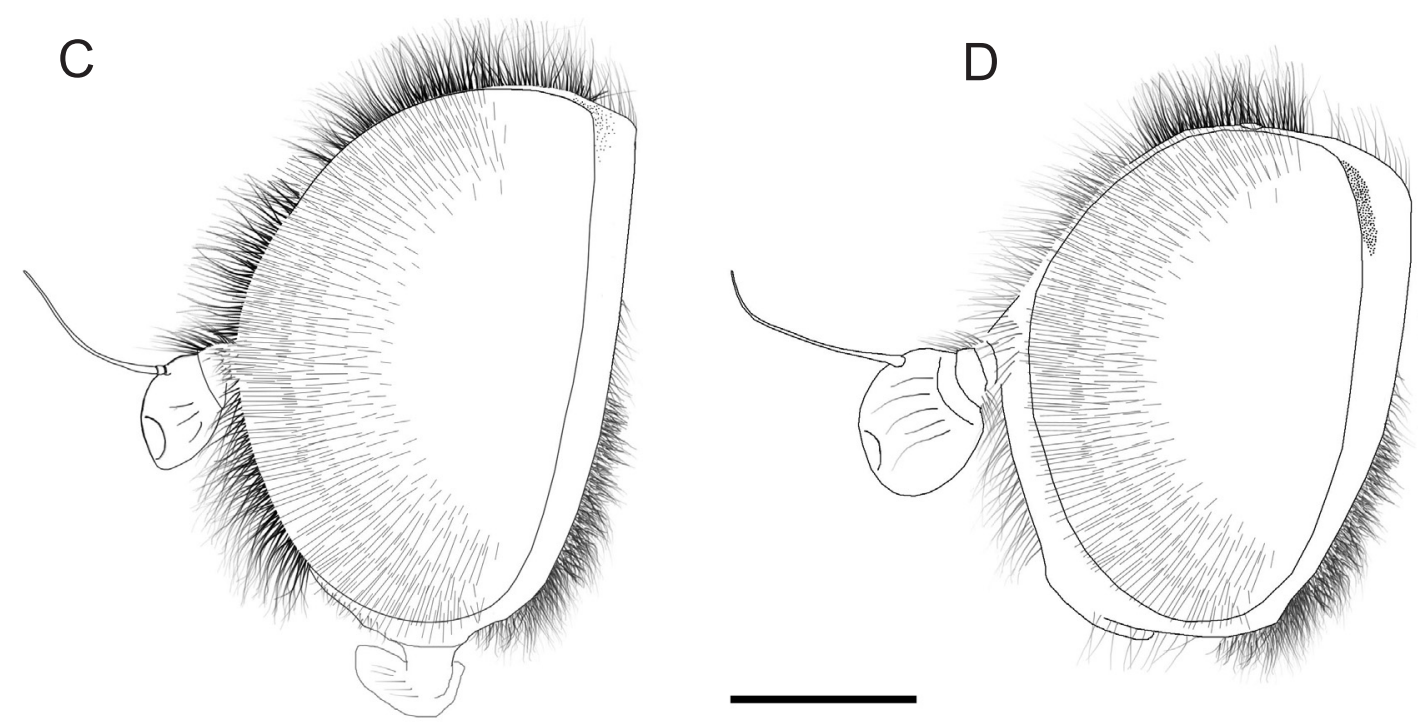

Figure 8. Eumerus niveitibia Becker, 1921, head: (A) male (specimen from Lesvos island), dorsal view; (B) female (specimen from mainland Greece), dorsal view; (C) male (specimen from Lesvos island), lateral view; (D) female (specimen from mainland Greece), lateral view. Scale bar $=1 \mathrm{~mm}$.

metafemur with a row of 9 thorn-like spinae on the anterior ridge of the ventral surface and a row of 8-9 thorn-like spinae on the posterior ridge (Fig. 9B); tergum I covered in short black pile; terga II-IV covered in black pile, except for the white pile on the pollinose maculae and antero-lateral part of tergum II; body pilosity shorter and not as dense as in male; terga black, with three pairs of wide white maculae, similar to those in male; sterna I-IV black, with brown pile; sternum II with pale and dark brown pile intermixed; tergum $\mathrm{V}$ with intermixed white and black pile.

Taxonomy notes. This species belongs to the E. tricolor group (see Taxonomic notes under
E. azabense sp. nov.). To separate this species from $E$. azabense sp. nov., see taxonomic notes of $E$. azabense sp. nov. In males of E. niveitibia, the colouration of body pile ranges from almost completely white (Fig. 7) to predominantly blackish brown. Males of E. azabense sp. nov. show a variable number of black pile in the lateral margins of terga II-IV. In Eumerus sinuatus Loew, 1855, another E. tricolor group species, colour of mesoscutum pile also varies, from golden yellow (specimens from unknown locality, deposited in the Museum für Naturkunde, Berlin) to predominantly black (specimens from Fruška Gora, Serbia). Thus, colouration of body pile appears to be a variable character in species of the $E$. tricolor group. 

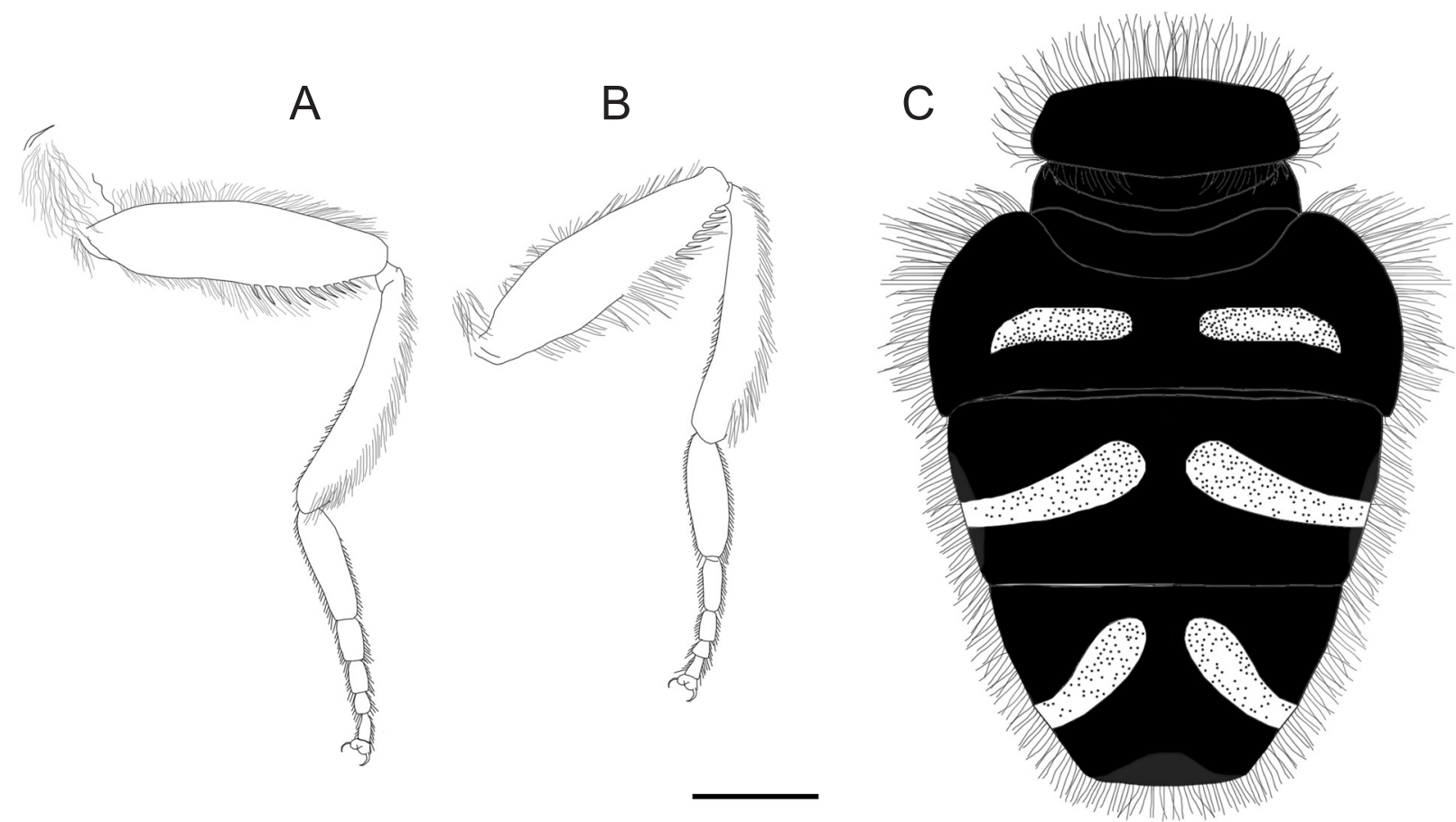

Figure 9. Eumerus niveitibia Becker, 1921: (A) leg, male (specimen from Lesvos island); (B) leg, female (specimen from mainland Greece); (C) abdomen, male (specimen from Lesvos island), dorsal view. Scale bar $=1 \mathrm{~mm}$.

\section{Molecular study}

The COI barcodes comprised 570 nucleotides for the total analysed dataset. The analysis supported the studied morphological species of Eumerus. The two analysed specimens of E. azabense sp. nov. shared the same COI haplotype and were separated clearly from the similar E. niveitibia (bootstrap value $=100$ ). In addition, the analysis clearly distinguished E. azaben$s e$ sp. nov. and $E$. ovatus which formed the same clade with $E$. sinuatus. Furthermore, monophyly of $E$. tricolor group was confirmed, since it separated from species of other groups (bootstrap value $=100$ ). The obtained ML tree shows that the new species, $E$. $a z a-$ bense sp. nov., clearly belongs to the $E$. tricolor group (Fig. 10).

Hoverfly survey in Campanarios de Azaba, Salamanca, Spain

We studied 645 hoverfly specimens representing 41 species of 19 genera. Examined material is listed below under each species. Species are presented in alphabetical order.

\section{Cheilosia brunnipennis Becker, 1894}

New to the Iberian Peninsula.
Examined material. 12.IV.2011: $2 ㅇ$ (Malaise 19), leg. Quinto, García and Quirce, det. Clauss Claussen.

Notes. Prior to the present study, this species was known from southern France and Morocco, apart from other regions of Europe. Thus, the presence of $C$. brunnipennis was expected in the Iberian Peninsula. Larva undescribed, presumably phytophagous.

\section{Chrysotoxum cisalpinum Rondani, 1845}

Examined material. 9.VII.2011: 10 (Malaise 2), 2 우 (Malaise 20), leg. García, Ramírez and Cortés; 9.VII.2011: 1 ㅇ (Malaise 20), leg. García, Ramírez and Moreno; 29/30.VII.2010: 1 ㅇ (Malaise 20), leg. Olmo Hernández; 29.IX.2011: 10 (Malaise 19), 1 ㅇ (Malaise 20), leg. Quinto, García and Ramírez.

Notes. This species is relatively widespread in Europe (see Speight 2015), but it has been rarely recorded in the Iberian Peninsula. Gil Collado (1930) states that C. cisalpinum is present in the localities of Villaverde, El Pardo (Madrid province) and Seseña (Toledo province), central Spain. However, he erroneously affiliated Seseña to Madrid province and this led MarcosGarcía et al. (1998) - and Ricarte and Marcos-García (2017) - to state that $C$. cisalpinum was recorded only from Madrid. This species was also recorded from Madrid by Leclercq (1963). Thus, the material examined in the present study adds Salamanca to the list of 
Spanish provinces where this species has been recorded. Larva undescribed, presumably predatory.

\section{Chrysotoxum intermedium Meigen, 1822}

Examined material. 12.IV.2011: 2 §ิ §ิ (Malaise 20), $1+$ (Malaise 1), leg. Quinto, García and Quirce;

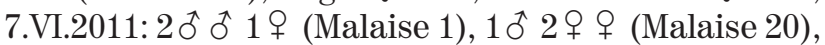
leg. Quinto, García and Ramírez.

Notes. Larva undescribed, presumably predatory (Rojo et al. 2003).

\section{Chrysotoxum octomaculatum Curtis, 1837}

Examined material. 9.VII.2011: 10 1우 (Malaise 1), 10 (Malaise 2), leg. García, Ramírez and Cortés;
29/30.VII.2010: 1 우 (Malaise 2), leg. Olmo Hernández; 7.VI.2011: 3 우 우 10 (Malaise 1); 10 (Malaise 2), 1 우 (Malaise 19), leg. Quinto, García and Ramírez.

Notes. Larva undescribed, presumably predatory.

\section{Chrysotoxum vernale Loew, 1841}

Examined material. 6.V.2011: 19 (Malaise 19); 7.VI.2011: 1 9 (Malaise 19), leg. Quinto, García and Ramírez.

Notes. Larva undescribed, presumably predatory.

Didea fasciata Macquart, 1834

Examined material. 7.VI.2011: 19 (Malaise 1), 19 (Malaise 19) leg. Quinto, García and Ramírez.

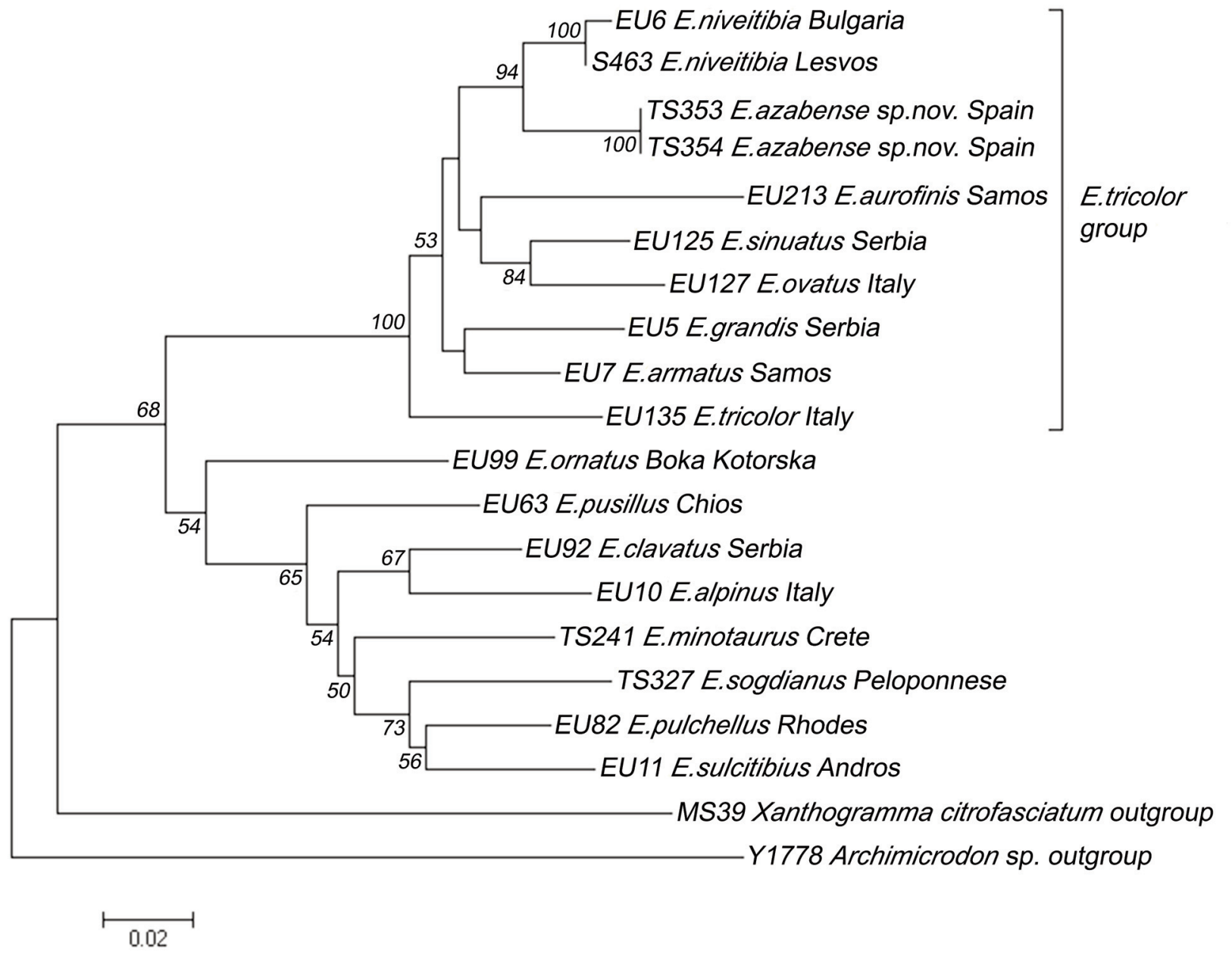

Figure 10. ML tree based on COI barcode sequences for species of the Eumerus tricolor and other Eumerus groups analysed in the present study. Values of bootstrap support are depicted near the nodes $(>50)$. 
Notes. Prior to the present study, D. fasciata was known from Spain and Portugal but it wasn't recorded from Salamanca province. Larva described, predatory.

\section{Epistrophe eligans (Harris, 1780)}

Examined material. 6.V.2011: 19 (Malaise 1), 19 (Malaise 20); 7.VI.2011: 1 우 (Malaise 20), leg. Quinto, García and Ramírez.

Notes. Larva described, predatory.

\section{Epistrophe nitidicollis (Meigen, 1822)}

Examined material. 7.VI.2011: 10 (Malaise 20), leg. Quinto, García and Ramírez.

Notes. Larva described, predatory.

\section{Episyrphus balteatus (De Geer, 1776)}

Examined material. 27/28.IX.2010: 10 (WT 5.1), leg. Olmo Hernández.

Notes. Larva described, predatory.

\section{Eristalis similis (Fallén, 1817)}

Examined material. 6.V.2011: 10े (WT 20.2); 7.VI.2011: 1 ㅇ (Malaise 1), 1 ㅇ (Malaise 19), leg. Quinto,

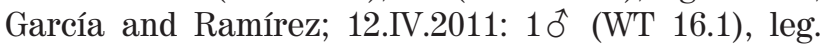
Quinto, García and Quirce; 20/22.V.2010: 10 (ALCORNOQUE, 'cork oak, Quercus suber'), leg. Micó, Quinto and Briones.

Notes. Larva described, saprophagous.

Eumerus azabense Ricarte \& Marcos-García sp. nov. (See new species description)

\section{Eumerus pulchellus Loew, 1848}

Examined material. 29/30.VII.2010: 1 우 (Malaise 19), leg. Olmo Hernández.

Notes. Larva described, phytophagous.

\section{Eupeodes corollae (Fabricius, 1794)}

Examined material. 26.VI.2010: 20 t 1 우 (Malaise 10); 27.VI.2010: 1 to 4 우 우 (Malaise 3); 29/30.VII.2010: 10 (WT 15.1), 1 우 (WT 18.1), leg. Hernández and Briones; 26.VI.2010: 1 ㅇ (Malaise 20), leg. Micó, Quinto and Briones; 6.V.2011: 1 ㅇ (Malaise 2), leg. Olmo

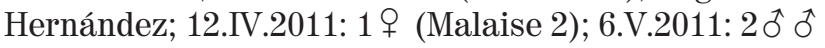
1 우 (Malaise 1); 7.VI.2011: $1{ }^{\widehat{t}}$ (Malaise 2), 1 우 (Malaise

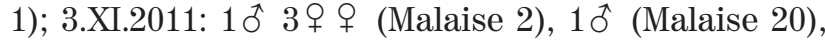
leg. Quinto, García and Ramírez.

Notes. Larva described, predatory.

Eupeodes latifasciatus (Macquart, 1829)

Examined material. 12.IV.2011: 1 ㅇ (Malaise 19), leg. Quinto, García and Quirce; 7.VI.2011: 1 ㅇ (Malaise 1), 1 (Malaise 2), 1 (Malaise 3), leg. Quinto, García and Ramírez.

Notes. Larva described, predatory.

Eupeodes lucasi (Marcos-García \& Láska, 1983)

Examined material. 27.VI.2010: 1 ㅇ (Malaise 3), leg. Hernández and Briones; 6.V.2011: 1 ㅇ (Malaise 2); 7.VI.2011: $1 \delta^{\Uparrow}$ (Malaise 2); 3.XI.2011: $1 \delta^{\hat{0}}$ (Malaise 20), leg. Quinto, García and Ramírez.

Notes. Larva undescribed, presumably predatory.

Ferdinandea aurea Rondani, 1844

Examined material. 3.I.2011: 2 तิ $\widehat{0}$ (Malaise 20);

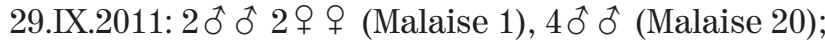
3.XI.2011: $1 \widehat{\delta}$ (Malaise 19), $4 \hat{\delta} \hat{\delta} 19$ (Malaise 20), $1 \hat{\sigma}$ (ET 19), leg. Quinto, García and Ramírez.

Notes. Larva undescribed, saproxylic. Adults have been collected from tree rot holes in Quercus faginea and Q. pyrenaica (Ricarte et al. 2010).

\section{Ferdinandea cuprea (Scopoli, 1763)}

Examined material. 14.VII.2011: 19 (T-Cerveza C13-3), 19 (T-Cerveza C6.4), $10^{\Uparrow} 1+$ (T-Cerveza Clab2), leg. García, Ramírez and Cortés; 2.VIII.2011: 1ठิ (T-Cerveza C13-4), leg. García, Ramírez and Moreno.

Notes. This species is widespread and unthreatened in Europe. However, there are no enough data about its abundance in the Iberian Peninsula where it is restricted to its northern area and where it appears to be rarer than $F$. aurea and $F$. fumipennis. Larva described, saproxylic.

\section{Ferdinandea ruficornis (Fabricius, 1775)}

Examined material. 14.VII.2011: 19 (T-Cerveza Clab2), leg. García, Ramírez and Cortés.

Notes. This species is considered to be threatened with extinction in Europe. Larva undescribed, presumably saproxylic and apparently associated to the burrows of Cossus cossus caterpillars. 
Melanostoma mellinum (Linneaus, 1758)

Examined material. 9.VII.2011: 10 우 (Malaise 2), leg. García, Quinto and Cortés; 7.VI.2011: 1 శ (Malaise 2); 9.VII.2011: $1 \widehat{\widehat{0}} 3$ 우 우 (Malaise 1), $6 \widehat{0} \widehat{0}$

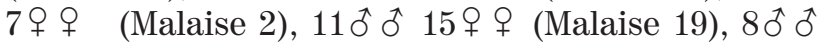
9 우 (Malaise 20), leg. García, Ramírez and Cortés;

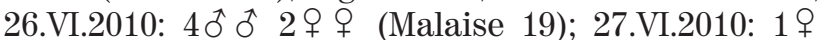
(WT 18.2), leg. Hernández and Briones; 26.VI.2010: 2 우 (Malaise 20), leg. Micó, Quinto and Briones; 29/30.VII.2010: $1 \overbrace{}^{\Uparrow}$ (Malaise 19), leg. Olmo Hernández; 6.V.2011: 2 우 우 (Malaise 1), 1 우 (Malaise 19), 1 우

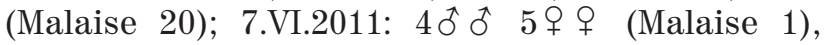

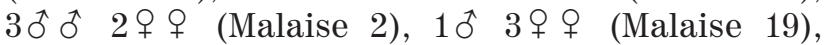
2 우 우 (Malaise 20); 9.VII.2011: $2 \hat{\widehat{\partial}} \widehat{0}$ (Malaise 20); 29.IX.2011: 1 ㅇ (Malaise 19), leg. Quinto, García and Ramírez.

Notes. Larva described, predatory.

Melanostoma scalare (Fabricius, 1794)

Examined material. 9.VII.2011: 2 $q$ (Malaise 1), 10 (Malaise 2), leg. García, Ramírez and Cortés;

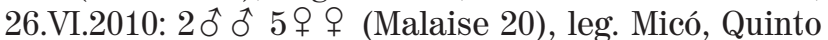
and Briones; 12.IV.2011: $2 \hat{\delta} \hat{\delta}$ (Malaise 2), $1 \hat{\delta}$ (Malaise 19), 1 우 (WT 19.2), Quinto, García and Quirce; 12.IV. 2011: 1 ô (Malaise 19); 7.VI.2011: 1 우 (Malaise 1), 10 (WT 3.1), $10^{\star}$ (WT 19.2), Quinto, García and Ramírez.

Notes. Larva described, predatory.

\section{Meliscaeva auricollis (Meigen, 1822)}

Examined material. 27/28.XI.2010: 1 우 (WT 15.1), leg. Hernández and Briones; 7.VI.2011: 10 to 1 (Malaise 20), leg. Quinto, García and Ramírez.

Notes. Larva described, predatory.

\section{Merodon chalybeus Wiedemann in Meigen, 1822}

Examined material. 27/28. IX.2010: $29 q$ (Malaise 20), leg. Olmo Hernández; 7.VI.2011: 1 ㅇ (Malaise 2), leg. Quinto, García and Ramírez, det. A. Vujić.

Notes. Larva undescribed, presumably phytophagous.

\section{Merodon clavipes (Fabricius, 1781)}

Examined material. 7.VI.2011: 1 우 (Malaise 2), leg. Quinto, García and Ramírez.

Notes. Larva undescribed, presumably phytophagous.
Merodon geniculatus Strobl in Czerny \& Strobl, 1909

Examined material. 7.VII.2011: $2 \uparrow q$ (Malaise 2), leg. Quinto, García and Ramírez, det. A. Vujić.

Notes. Larva undescribed, presumably phytophagous.

Merodon ibericus Vujić in Popović et al., 2015

Examined material. 9.VII.2011: 19 (Malaise 2), leg. García, Quinto and Cortés. 7.VI.2011: 1 ㅇ (Malaise 1), leg. Quinto, García and Ramírez

Notes. Larva undescribed, presumably phytophagous.

Merodon italicus Rondani, 1845

Examined material. 9.VII.2011: 1 우 (Malaise 19), García, Quinto and Cortés; 2.VIII.2011: 10 (Malaise 19), leg. García, Ramírez and Moreno.

Notes. Larva undescribed, presumably phytophagous.

Merodon obscuritarsis Strobl in Czerny, 1909

Examined material. 6.V.2011: 19 (Malaise 19); 7.VI.2011: 1 ㅇ (Malaise 2), leg. Quinto, García and Ramírez.

Notes. Larva undescribed, presumably phytophagous.

Paragus bicolor (Fabricius, 1794)

Examined material. 9.VII.2011: $2 q q$ (Malaise 2), $3 q q$ (Malaise 19), leg. García, Ramírez and Cortés; 2.VIII.2011: 1 †ิ (Malaise 19), leg. García, Ramírez and Moreno; 27.VI.2010: 1 ㅇ (Malaise 3), leg. Hernández and Briones; 26.VI.2011: 2 우 (Malaise 20), leg. Micó, Quinto and Briones; 7.VI.2011: $1+$ (Malaise 19), leg. Quinto, García and Ramírez.

Notes. Larva undescribed, but apparently predatory on aphids found in Rumex (Gomes, 1981).

Paragus haemorrhous Meigen, 1822

Examined material. 9.VII.2011: 1 우 (Malaise 2), leg. García, Ramírez and Cortés; 26.VI.2010: 1 ㅇ (Malaise 20); 26.VI.2011: 1 ㅇ (Malaise 20), leg. Micó, Quinto and Briones; 7.VI.2011: 1 ㅇ (Malaise 19), leg. Quinto, García and Ramírez.

Notes. Larva described, predatory. 


\section{Paragus pecchiolii Rondani, 1857}

Examined material. 7.VI.2011: 1 우 (Malaise 2), leg. Quinto, García and Ramírez.

Notes. Larva described, predatory.

\section{Paragus quadrifasciatus Meigen, 1822}

Examined material. 9.VII.2011: 19 (Malaise 2), leg. García, Ramírez and Cortés; 2.VIII.2011: 1 đ (Malaise 2), leg. García, Ramírez and Moreno; 29/30.VII. 2010: 1 (Malaise 19), 1 $q$ (Malaise 20), leg. Olmo Hernández.

Notes. Larva described, predatory.

\section{Paragus strigatus Meigen, 1822}

Examined material. 9.VII.2011: 19 (Malaise 1), 1 ㅇ (Malaise 2), 1 ㅇ (Malaise 20), leg. García, Ramírez

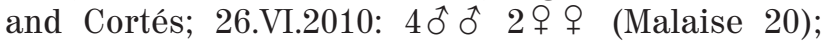
26.VI.2011: 1 q (Malaise 20), leg. Micó, Quinto and

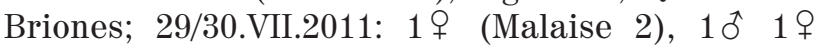
(Malaise 20), leg. Olmo Hernández; 7.VI.2010: 10 (Malaise 2); 7.VI.2011: $1 \widehat{ } 1$ 우 (Malaise 2); 29.IX.2011: $1 \hat{\widehat{T}}$ (Malaise 1), leg. Quinto, García and Ramírez; 27.VI.2010: 1 ㅇ (WT 18.2), leg. Hernández and Briones.

Notes. Larva undescribed, presumably predatory.

\section{Paragus tibialis (Fallén, 1817)}

Examined material. 9.VII.2011: 10 (Malaise 2), leg. García, Quinto and Cortés; 9.VII.2011: 10 수 (Malaise 2), 1 đ (Malaise 20), leg. García, Ramírez and Cortés; 2.VIII.2011: 1 đ (Malaise 1), 1 ㅇ (Malaise 19), leg. García, Ramírez and Moreno; 26.VI.2010: 3 q $q$ (Malaise 19); 27.VI.2010: $4 \hat{\delta} \widehat{o} 10 ㅇ ㅇ$ (Malaise 3), leg. Hernández and Briones; 26.VI.2010: 10 우 우 (Malaise

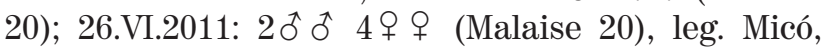

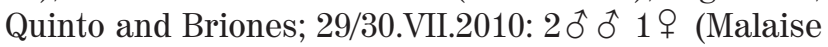
20), Olmo Hernández.

Notes. Larva undescribed, predatory. Information on the biology of this aphid-feeding larva is provided by Marcos-García (1981).

\section{Paragus vandergooti Marcos-García, 1986}

Examined material. 9.VII.2011: $3 q q$ (Malaise 2) leg. García, Ramírez and Cortés; 2.VIII.2011: 1 q (Malaise 19), leg. García, Ramírez and Moreno; 26.VI. 2010: 1 ㅇ (Malaise 10), leg. Hernández and Briones; 29/30.VII.2010: 1 우 (Malaise 19), $2 ㅇ$ (Malaise 20), Olmo Hernández.

Notes. Larva undescribed, presumably predatory.

\section{Pelecocera lusitanica (Mik, 1898)}

Examined material. 29.IX.2011: 10 (Malaise 1); 3.XI.2011: 1 ㅇ (ET 19), leg. Quinto, García and Ramírez.

Notes. Larva undescribed, presumably phytophagous.

\section{Scaeva pyrastri (Linnaeus, 1758)}

Examined material. 27.VI.2010: 1 우 (Malaise 3), leg. Hernández and Briones.

Notes. Larva described, predatory.

\section{Sphaerophoria scripta (Linnaeus, 1758)}

Examined material. 29/30.VII.201: 10 수 1 우

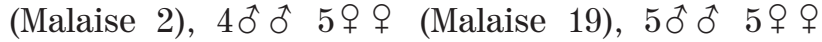

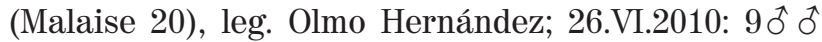

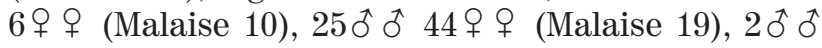

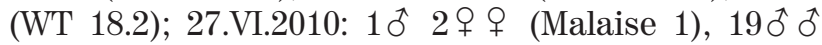
12 우 (Malaise 3); 26.VI.2011: 10 (Malaise 10), leg. Hernández and Briones; 9.VII.2011: 4 우 우 (Malaise 2), leg. García, Quinto, Cortés; 9.VII.2011: $80 \widehat{0} 5$ 우 (Malaise 1), $6 \hat{0} \widehat{\widehat{0}} 8$ 우우 (Malaise 2), $2 \hat{0} \widehat{0} 5$ 우우 (Malaise 20), leg. García, Ramírez and Cortés; 2.VIII.2011: $20 \hat{\delta} 2+q$ (Malaise 19), 1 우 (Malaise 20), leg. García, Ramírez and Moreno; 26.VI.

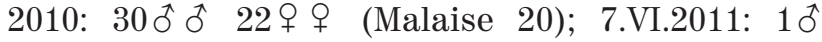
(Malaise 20); 26.VI.2011: $17 \delta \widehat{\delta} 3$ 우 우 (Malaise 20), leg. Micó, Quinto and Briones; 12.IV.2011: $10^{\pi} 1$ ㅇ (Malaise 19), leg. Quinto, García and Quirce; 26.VI.2010: 10 (Malaise 20); 12.IV.2011: 1 우 (Malaise 19), 1 우 (Malaise 20); 6.V.2011: $1 \delta^{\Uparrow} 4 ㅇ+$ (Malaise 1), 1 을 (Malaise 2), 4 우 (Malaise 19), 2 우 (Malaise 20);

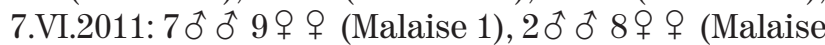

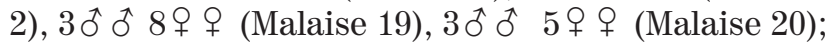
6.IX.2011: 1 ㅇ (Malaise 19); 29.IX.2011: $1+$ (Malaise 1), 3.XI.2011, 2 우 (Malaise 20), leg. Quinto, García and Ramírez.

Notes. Larva described, predatory.

\section{Syrphus vitripennis Meigen, 1822}

Examined material. 12.IV.2011: 10 (Malaise 19), leg. Quinto, García and Quirce.

Notes. Larva described, predatory.

\section{Volucella elegans Loew, 1862}

Examined material. 7.VI.2011: 10 (WT 3.1), leg. Quinto, García and Ramírez.

Notes. Larva undescribed. 


\section{Volucella inanis (Linneaus, 1758)}

Examined material. 27/28.IX.2010: $1 \uparrow$ (Malaise 19), Olmo Hernández.

Notes. Larva described, the $1^{\text {st }}$ and $2^{\text {nd }}$ instars are parasitic in wasps' nests, on larvae of Vespula germanica and $V$.vulgaris, while the $3^{\text {rd }}$ instar is more a parasitoid.

\section{Xanthogramma marginale (Loew, 1854)}

Examined material. 7.VI.2011: 19 (Malaise 19), leg. Quinto, García and Ramírez.

Notes. Larva undescribed, presumably predatory.

\section{DiscussiON}

As a result of the survey carried out in the oak dehesa of Campanarios de Azaba, 41 hoverfly species were collected, including a species new to science, Eumerus azabense sp. nov., and a species new to the Iberian Peninsula, Cheilosia brunnipennis. In addition, and according to Ramírez-Hernández et al. (2015b) and Ricarte and Marcos-García (2017), two species were new to Salamanca province, Chrysotoxum cisalpinum and Didea fasciata. In total, 56 hoverfly species are recorded at present from the dehesa of Campanarios de Azaba (see Appendix 1). Paragus and Merodon had the highest number of species amongst the 19 genera recorded, with 7 and 6 species respectively. In fact, Merodon is the second Eristalinae genus with more species recorded in Spain and Paragus the first Syrphinae genus (Ricarte and Marcos-García 2017). Dehesa is a typical Mediterranean ecosystem in which species of Paragus and Merodon are abundant because of their mainly Mediterranean distribution. However, Cheilosia, which is the richest genus in Spain (Ricarte and Marcos-García 2017), is poorly represented in this oak dehesa due to the fact that it has its highest species diversity further north, in the Cantabrian mountain range and near areas (MarcosGarcía 1990, Ricarte et al. 2014).

The new species, Eumerus azabense sp. nov., was found to be morphologically similar to E. niveitibia; for example, they shared similar male genitalia (Fig. $6)$. However, molecular analyses confirmed that E. azabense sp. nov. and E. niveitibia were clearly separate species (Fig. 10). Thus, the present study is another example of how useful an integrative approach (morphological and molecular data) can be in delimiting species borders. In addition, obtaining the DNA barcode of $E$. azabense sp. nov. might be useful for future studies, when Eumerus larvae are encountered in the study area. To build a complete DNA barcode database of hoverflies may help in identification of early stages, when rearing is an impossible or unsuccessful process (Ståhls et al. 2009, Andrić et al. 2014). This application of DNA barcodes is even more important for genera such as Eumerus and Merodon, which are especially diverse in taxonomic terms, have poorly known larval biology and include a few species causing damage in commercial plants (Ricarte et al. 2008). To enhance the knowledge of early stages is actually one of the main challenges of current syrphidology; for example, the larvae of 20 of the 41 species recorded in Campanarios de Azaba are undescribed.

Most species found during the course of the present study have, or are meant to have, predatory larvae (27 spp.). The presence and abundance of hoverfly species that are natural predators of a wide range of homopterans (pest insects) is greatly important for pest control (Bugg et al. 2008). On the one hand, dehesas may play a key role as refuges and reproduction areas of natural enemies that assist in controlling the pests of neighbouring crops. Many predatory species recorded in Campanarios de Azaba are migratory (e.g. S. scripta, $E$. balteatus, E. corollae) and move easily among different areas (Speight 2015) within the Iberian Peninsula. On the other hand, dehesas may act as prey reservoirs for predatory hoverflies of crops during periods of low infestation (Bortolotto et al. 2016).

Only four saproxylic species were found in the present study. However, 18 saproxylic species were collected by Ramírez-Hernández et al. (2015b) in this area, with emergence traps and window traps. The underrepresentation of species with saproxylic habits in the present study is due to the sampling technique. In fact, Malaise traps have not proven useful to collect certain hoverfly species in other habitats and regions (e.g. Burgio and Sommaggio 2007, Marcos-García et al. 2012). Thus, the combination of different sampling methods is necessary to get a complete inventory of the hoverfly diversity of a Mediterranean habitat (Ricarte and Marcos-García, 2008).

Within the saproxylics, $F$. ruficornis was collected during the course of the present study. This is a species considered to be threatened with extinction in most of its European range (Speight 2015). Prior to this survey, $F$. ruficornis was collected only from a locality in Spain, the Cabañeros National Park, where it was found in Q. pyrenaica forests (Ricarte et al. 2010). Campanarios is also the habitat of many other saproxylic hoverflies of genera such as Callicera, Mallota, Myolepta, Sphiximorpha and Spilomyia (see Appendix 1). This saproxylic community of hoverflies is sustained thanks to the presence of suitable microhabitats for their larvae, i.e. rot holes and sap runs in trees (Ramírez-Hernández et al. 2015a).

Dehesas are productive systems that require a better use of natural resources and production 
optimisation. Hoverflies can be used as management stools with Syrph the Net, the database of European Syrphidae (StN) (Speight et al. 2010 in combination with Monteil 2010). The present paper represents an important step towards the consolidation of hoverflies as management tools in this habitat, since provides data on association hoverfly-habitat for 41 species and updates the species list of Salamanca province (152 spp., see Appendix 1). A new habitat category for dehesa will eventually be coded in future versions of StN based on the data provided in the present study, as well as other data from other studies.

Dehesas are 'mosaic landscapes' generated after a long history of human use; grassland, scrubland and woodland components are combined in this landscape (Fig. 1), like in other similar landscapes such as 'raña', in Cabañeros National Park. In these mosaic landscapes, turnover among different components of the landscape (beta diversity) has a high specific weight in the total biodiversity (Ricarte et al. 2011). Other studies on the dehesa insects have shown the importance of this landscape as a biodiversity reservoir (e.g. Viejo et al. 1989; Ramírez-Hernández et al. 2014). Within this habitat biodiversity, there are individual species that can act as flagships for conservation, for example the threatened $F$. ruficornis, or the new E. azabense sp. nov., which might be endemic of this habitat type. In addition, the Vulnerable M. dusmeti Andréu, 1926 is also present in Campanarios (Ramírez-Hernández et al. 2015b). For these and other reasons stated in this paper, dehesas should be treated as key Mediterranean ecosystems in which biodiversity maintenance and stockbreeding production combine.

\section{ACKNOWLEDGEMENTS}

We would like to thank all people that assisted in field work. Financial support was provided by the project LIFE-NATURE 'Conservación de la Biodiversidad en el Oeste Iberico' (LIFE/E/NAT/000762). We also thank the 'Naturaleza y Hombre' Foundation for facilitating fieldwork in this protected area. The current fellowship of Antonio Ricarte at the University of Alicante is supported by the 'Vicerrectorado de Investigación y Transferencia de Conocimiento'.

\section{REFERENCES}

Andrić, A., Šikoparija, B., Obreht, D., Đan, M., Preradović, J., Radenković, S., Pérez-Bañón, C. and A. Vujić. 2014. DNA barcoding applied: identifying the larva of Merodon avidus (Diptera: Syrphidae). Acta Entomologica Musei Nationalis Pragae, 54(2): 741-757.

Bartsch, H., Binkiewicz, E., Rådén, A. and E. Nasibov. 2009a. Blomflugor: Syrphinae. Nationalnyckeln till Sveriges flora och flora, DH53a. Artdatabanken, SLU, Uppsala, $406 \mathrm{pp}$.

Bartsch, H., Binkiewicz, E., Klintbjer, A., Rådén, A. and E. Nasibov. 2009b. Blomflugor: Eristalinae \& Microdontinae. Nationalnyckeln till Sveriges flora och flora, DH 53b. Artdatabanken, SLU, Uppsala, 478 pp.

Becker, T. 1921. Neue Dipteren meiner Sammlung. I. Syrphidae. Mitteilungen aus dem Zoologischen Museum in Berlin, 10, 1-93.

Bortolotto, O. C., De Oliveira Menezes Júnior, A., Thibes Hoshino, A. and T. A. Campos. 2016. Distance from edge of forest fragments influence the abundance of aphidophagous hoverflies (Diptera; Syrphidae) in wheat fields. Acta Scientiarum, Agronomy, 38(2): 157-164.

Bugalho, M. N., Caldeira, M. C., Pereira, J. S., Aronson, J. and J. G. Pausas. 2011. Mediterranean cork oak savannah requires human use to sustain biodiversity and ecosystem services. Frontiers in Ecology and the Environment, 9(5): 278-286.

Bugg, R. L., Colfer, R. G., Chaney, W. E., Smith, H. A. and J. Cannon. 2008. Flower Flies (Syrphidae) and Other Biological Control Agents for Aphids in Vegetable Crops. ANR Publication, 8285, 25 pp.

Burgio, G. and D. Sommaggio. 2007. Syrphids as landscape bioindicator in Italian agroecosystems. Agriculture, Ecosystem and Environment, 120: 416-422.

Campos, P., Huntsinger, L., Oviedo, J. L., Starrs, P. F., Díaz, M., Standiford, R. B. and G. Montero. 2013. Mediterranean oak woodland working landscapes (Landscape Series, number 16). Springer Netherlands, 508 pp.

Chen, H., Rangasamy, M., Tan, S. Y., Wang, H. and B. D. Siegfried. 2010. Evaluation of five methods for total DNA extraction from western corn rootworm beetles. PLoS One, 5(8): e11963. doi: 10.1371/journal. pone.0011963 PMID: 20730102.

Chroni, A., Đan, M., Obreht-Vidaković, D., Petanidou, T. and A. Vujić. 2017. Molecular species delimitation in the genus Eumerus (Diptera: Syrphidae). Bulletin of Entomological Research, 107(1): 126-138.

Claussen, C. 1989. Syrphiden aus Marokko (Diptera, Syrphidae). Entomofauna, 10(24), 357-376.

Folmer, O., Black, M. and W. Hoeh. 1994. DNA primers for amplificationof mitochondrial cytochrome c oxidase subunit I fromdiverse metazoan invertebrates. Molecular Marine Biologyand Biotechnology, 3: 294-299.

Galante, E., García-Román, M., Barrera, I. and P. Galindo. 1991. Comparison of spatial distribution patterns of dungfeeding scarabs (Coleoptera: Scarabaeidae, Geotrupidae) in wooded and open pastureland in the Mediterranean "Dehesa" area of the Iberian Peninsula. Environmental Entomology, 20(1): 90-97.

Gil-Collado, J. 1930. Monografía de los Sírfidos de España. Trabajos del Museo Nacional de Ciencias Naturales, Serie Zoológica, Núm. 54, Madrid, 376 pp.

Goeldlin de Tiefenau, P. 1976. Revision du genre Paragus (Dipt., Syrphidae) de la region palearctique occidentale. Bulletin de la Société Entomologique Suisse, 49: 79-108.

Gomes, A. 1981. Sirfideos colhidos em Portugal durante 1977 (Diptera, Syrphidae). Agronomialusitana, 41: 5-24.

Grković, A., Vujić, A., Radenković, S., Chroni, A. and T. Petanidou. 2015. Diversity of the genus Eumerus Meigen 
(Diptera, Syrphidae) on the eastern Mediterranean islands with description of three new species. Annales de la Société Entomologique de France (N.S.), 51(4): 361-373.

Grković, A., Vujić, A., Chroni, A., van Steenis J., Đan, M. and S. Radenković. 2017. Taxonomy and systematics of three species of the genus Eumerus Meigen, 1822 (Diptera: Syrphidae) new to southeastern Europe. Zoologischer Anzeiger, 270: 176-192.

Haarto, A. and G. Ståhls. 2014. When mtDNA COI is misleading: congruent signal of ITS2 molecular marker and morphology for North European Melanostoma Schiner, 1860 (Diptera, Syrphidae). ZooKeys, 431: 93-134.

Hall, T. A. 1999. BioEdit: a user-friendly biological sequence alignment editor and analysis program for windows 95/ 98/NT. - Nucleic acids symposium series.

Kress, W. J., García-Robledo, C., Uriarte, M. and D. L. Erickson. 2015. DNA barcodes for ecology, evolution, and conservation. Trends in Ecology \& Evolution, 30(1): 25-35.

Kumar, S., Stecher, G. and K. Tamura. 2016. MEGA7: Molecular Evolutionary Genetics Analysis version 7.0 for bigger datasets. Molecular Biology and Evolution, 33: 1870-1874.

Leclercq, M. 1963. Syrphidae de España (Diptera). Graellsia, 20: $125-129$.

Marañón, T. 1991. Diversidad en comunidades de pasto mediterráneo: modelos y mecanismos de coexistencia. Ecología, 5: 149-157.

Marchese, C. 2015. Biodiversity hotspots: A shortcut for a more complicated concept. Global Ecology and Conservation, 3: 297-309.

Marcos-García, M. A. 1981. Contribución al conocimiento de los Syrphidae (Diptera) de la zona noreste de la provincia de Salamanca. Boletín de la Asociación española de Entomología, 4: 75-78.

Marcos-García, M. A. 1985. Los Syrphidae (Díptera) de las sierras occidentales del Sistema Central español: Subfamilias: Eristalianae, Lampettiinae, Microdontinae, Milesiinae y Cerianinae. Boletín de la Asociación española de Entomología, 9: 187-210.

Marcos-García, M. A. 1990. El género Cheilosia Meigen, 1882, en la Cordillera Cantábrica (Diptera: Syrphidae). Mediterránea, Series de Estudios Biológicos, 12: 113-118.

Marcos-García, M. A., Isidro, P. M., Rojo, S. and C. PérezBañón. 1998. Catálogo y distribución geográfica de los sírfidos iberobaleares (Diptera, Syrphidae) I. - Syrphinae y Microdontinae. Boletín de la Asociación española de Entomología, 22(3-4): 37-61.

Marcos-García, M. A., Vujić, A. and X. Mengual. 2007. Revision of Iberian species of the genus Merodon (Diptera: Syrphidae). European Journal of Entomology, 104: 531-572.

Marcos-García, M. A., García-López, A., Zumbado, M. A. and G. E. Rotheray. 2012. Sampling Methods for Assessing Syrphid Biodiversity (Diptera: Syrphidae) in Tropical Forests. Environmental Entomology, 41(6): 1544-1552.

Mittermeier, R. A., Turner, W. R., Larsen, F. W., Brooks, T. M. and C. Gascon. 2011. Global biodiversity conservation: the critical role of hotspots, pp. 3-22. In: Zachos, F. E. and J. C. Habel (eds.). Biodiversity Hotspots. Springer Publishers, London.

Monteil, C. 2010. A Species Selection Tool for the "Syrph the Net" database. In: Speight, M.C.D., Castella, E., Sarthou,
J.-P. \&C. Monteil (eds.). Syrph the Net on CD, Issue 7. The database of European Syrphidae. ISSN 1649-1917. Syrph the Net Publications, Dublin.

Myers, N., Mittermeier, R. A., Mittermeier, C. G., da Fonseca, G. A. and J. Kent. 2000. Biodiversity hotspots for conservation priorities. Nature, 403: 853-858.

Nedeljković, Z., Ačanski, J., Obreht-Vidaković, D., Ricarte, A. and A. Vujić. 2015. An integrated approach to delimiting species borders in the genus Chrysotoxum Meigen, 1803 (Diptera: Syrphidae), with description of two new species. Contributions to Zoology, 84(4): 285-304.

Nei, M. and S. Kumar. 2000. Molecular Evolution and Phylogenetics. Oxford University Press, New York.

Olea, L. and A. San Miguel-Ayanz. 2006. The Spanish dehesa. A traditional Mediterranean silvopastoral system linking production and nature conservation. $21^{\text {st }}$ General Meeting of the European Grassland Federation, Badajoz (Spain). April 2006. Opening Paper.

Pape, T. and F. C. Thompson. 2013. Systema Dipterorum, Version 1.5. http://www.diptera.org/, accessed on $1^{\text {st }}$ February 2017.

Ramírez-Hernández, A., Micó, E., Marcos-García, M. A., Brustel, H. and E. Galante. 2014. The "dehesa", a key ecosystem in maintaining the diversity of Mediterranean saproxylic insects (Coleoptera and Diptera: Syrphidae). Biodiversity and Conservation, 23: 2069-2086.

Ramírez-Hernández, A., Micó, E. and E. Galante. 2015a. El ecosistemade dehesa como reservorio de diversidad de insectos saproxílicos (Coleoptera y Diptera: Syrphidae) y factores que determinan sus ensambles. Cuadernos de Biodiversidad, 47: 13-24.

Ramírez-Hernández, A., Micó, E., Marcos-García, M. A. and E. Galante. 2015b. Coleópteros y sírfidos saproxílicos (Coleoptera; Diptera: Syrphidae) de las dehesas del oeste ibérico: la Reserva Biológica de Campanarios de Azaba (Salamanca). Boletín de la Asociación Española de Entomología, 39(1-2): 133-158.

Ricarte, A. and M. A. Marcos García. 2008. Los sírfidos (Diptera: Syrphidae) del Parque Nacional de Cabañeros (España): una herramienta para la gestión. Boletín de la Asociación Española de Entomología, 32(1-2): 19-32.

Ricarte, A., Marcos-García, M. A. and G. E. Rotheray. 2008. The early stages and life histories of three Eumerus and two Merodon species (Diptera: Syrphidae) from the Mediterranean region. Entomologica Fennica, 19: 129-141.

Ricarte, A., Nedeljković, Z., Quinto, J. and M. A. Marcos-García. 2010. The genus Ferdinandea Rondani, 1844 (Diptera, Syrphidae) in the Iberian Peninsula: first records and new breeding sites. Journal of the Entomological Research Society, 12(3): 57-69.

Ricarte, A., Marcos-García, M. A. and C. E. Moreno. 2011. Assessing the effects of vegetation on hoverfly (Diptera: Syrphidae) diversity in a Mediterranean landscape: implication for conservation. Journal of Insect Conservation 15: 865-877.

Ricarte, A., Nedeljković, Z., Rotheray, G. E., Lyszkowski, R. M., Hancock, E. G., Watt, K., Hewitt, S. M., Horsfield, D. and G. Wilkinson. 2012. Syrphidae (Diptera) from the Greek island of Lesvos, with description of two new species. Zootaxa, 3175: 1-23.

Ricarte, A., Rotheray, G. E., Lyszkowski, R. M., Hancock, E. 
G., Hewitt, S. M., Watt, K. R., Horsfield, D. and I. MacGowan. 2014. The syrphids of Serra do Courel, Northern Spain and description of a new Cheilosia Meigen species (Diptera: Syrphidae). Zootaxa, 3793: 401-422.

Ricarte, A., Zaragoza, J. A. and M. A. Marcos-García. 2016. First record of a phoretic association between a hoverfly (Diptera, Syrphidae) and a pseudoscorpion (Arachnida, Pseudoscorpiones) in the Iberian Peninsula. Boletín de la Asociación española de Entomología, 40(3-4): 527-530.

Ricarte, A. and M. A. Marcos-García. 2017. A checklist of the Syrphidae (Diptera) of Spain, Andorra and Gibraltar. Zootaxa, 4216(5): 401-440.

Rojo, S., Gilbert, F., Marcos-García, M. A., Nieto, J. M. and M. P. Mier. 2003. A world review of predatory hoverflies (Diptera, Syrphidae: Syrphinae) and their prey. CIBIO Ediciones, Alicante, 319 pp.

Rotheray, G. E. and F. Gilbert. 2011. The Natural History of Hoverflies. Forrest Text, Ceredigion, UK, $334 \mathrm{pp}$.

Sack, P. 1932. Syrphidae. In: Lindner E. (ed.) Die Fliegen der Palaearktischen Region IV/6. Schweizerbart, Stuttgart. $451 \mathrm{pp}$.

Sánchez-Martínez, C., Benito Peñil, D., García De Enterría, S., Barajas Castro, I., Martín Herrero, N., Pérez Ruiz, C., Sánchez Sánchez, J., Sánchez Agudo, J. A., Rodríguez De La Cruz, D., Galante, E., Marcos-García, M. A. and E. Micó. 2012. Manual de gestión sostenible de bosques abiertos mediterráneos. Castilla Tradicional, Salamanca,148 pp.

Sommaggio, D. 1999. Syrphidae: can they be used as environmental bioindicators? Agriculture, ecosystems and environment, 74(1): 343-356.

Sommaggio, D. and G. Burgio. 2014. The use of Syrphidae as functional bioindicator to compare vineyards with different managements. Bulletin of Insectology, 67(1): 147-156.

Speight, M. C. D. 2014. Species accounts of European Syrphidae (Diptera). Syrph the Net, the database of European Syrphidae, vol. 78, Syrph the Net publications, Dublin, 321 pp.

Speight, M. C. D. 2015. Species accounts of European Syrphidae (Diptera), 2015. Syrph the Net, the database of
European Syrphidae, vol. 83, Syrph the Net publications, Dublin, 291 pp.

Stackelberg, A. A. 1961. Palaearctic species of the genus Eumerus Mg. (Diptera, Syrphidae). Trudy Vsesojuoznogo Entomologiceskogo Obscestva, 48: 18-229. [In Russian].

Ståhls, G., Vujić A., Pérez-Bañón, C., Radenković, S., Rojo, S. and T. Petanidou. 2009. COI barcodes for identification of Merodon hoverflies (Diptera, Syrphidae) of Lesvos Island, Greece. Molecular Ecology Resources, 9(6): 1431-1438.

Thompson, F. C. 1999. A key to the genera of the flower flies of the Neotropical Region including the descriptions of genera and species and a glossary of taxonomic terms. Contributions on Entomology, International, 3: 319-378.

Thompson, J. D., Higgins, D. G. and T. J. Gibson. 1994. Clustal In: Improving the sensitivity of progressive multiple sequence alignment through sequence weighting, positionspecific gap penalties and weigh matrix choice. Nucleic acids research 22.22(1994): 4673-4680.

Van Veen, M. 2004. Hoverflies of Northwest Europe: identification keys to the Syrphidae. KNNV Publishing, Utrecht, $256 \mathrm{pp}$.

Viejo, J. L., Viedma, M. G. and C. J. Ralph (eds.). 1989. The importance of woodlands in the conservation of butterflies (Lep.: Papilionoidea and Hesperioidea) in the centre of the Iberian Peninsula. Biological Conservation, 48: 101-114.

Violovitsh, N. A. 1974. A review of the Palaearctic species of the genus Chrysotoxum Mg. (Diptera, Syrphidae). Entomologocskoc obozrcnic (Entomological Review), 53: 196-217.

Vujić, A. and S. Simić. 1999. Genus Eumerus Meigen 1822 (Diptera: Syrphidae) in area of former Jugoslavia. Glasnik Prirodnjackog Muzeja u Beogradu, B, 49-50, 173-190.

Williams, K. J., Ford, A., Rosauer, D. F., De Silva, N., Mittermeier, R., Bruce, C., Larsen, F. W. and C. Margules. 2011. Forests of east Australia: the $35^{\text {th }}$ biodiversity hotspot, pp. 295-310. In: Zachos, F. E. and J. C. Habel (eds.). Biodiversity Hotspots. Springer Publishers, London. 
Appendix 1. A checklist of the Syrphidae of Salamanca province, Spain (152 spp.). Species recorded in Campanarios de Azaba (56 spp.) are indicated with 'CA' after the species name. Species written in bold are new to Salamanca. This species list is based on Ramírez-Hernández et al. (2015b), Ricarte and Marcos-García (2017) and results of the present study.

Brachypalpus valgus (Panzer, 1798)

Callicera aenea (Fabricius, 1777)

Callicera fagesii Guerin-Meneville, $1844^{\mathrm{CA}}$

Callicera macquarti Rondani, $1844^{\mathrm{CA}}$

Callicera spinolae Rondani, $1844^{\mathrm{CA}}$

Ceriana conopsoides (Linnaeus, 1758)

Ceriana vespiformis (Latreille, 1804) ${ }^{\mathrm{CA}}$

Cheilosia aerea Dufour, 1848

Cheilosia albitarsis (Meigen, 1822)

Cheilosia andalusiaca Torp Pedersen, 1971

Cheilosia brunnipennis Becker, 1894 CA

Cheilosia gigantea (Zetterstedt, 1838)

Cheilosia latifrons (Zetterstedt, 1843)

Cheilosia mutabilis (Fallén, 1817)

Cheilosia paralobi Malski, 1962

Cheilosia scutellata (Fallén, 1817)

Cheilosia variabilis (Panzer, 1798)

Cheilosia vernalis (Fallén, 1817)

Chrysogaster basalis Loew, 1857

Chrysogaster solstitialis (Fallén, 1817)

Chrysotoxum bicinctum (Linnaeus, 1758)

Chrysotoxum cautum (Harris, 1776)

Chrysotoxum cisalpinum Rondani, $1845^{\mathrm{CA}}$

Chrysotoxum festivum (Linnaeus, 1758)

Chrysotoxum intermedium Meigen, $1822{ }^{\mathrm{CA}}$

Chrysotoxum latifasciatum Becker, 1921

Chrysotoxum octomaculatum Curtis, $1837^{\mathrm{CA}}$

Chrysotoxum vernale Loew, $1841^{\mathrm{CA}}$

Dasysyrphus albostriatus (Fallén, 1817)

Dasysyrphus pinastri (De Geer, 1776)

Didea fasciata Macquart, $1834 \mathrm{CA}$

Epistrophe eligans (Harris, 1780) ${ }^{\mathrm{CA}}$

Epistrophe flava Doczkal \& Schmid, 1994

Epistrophe nitidicollis (Meigen, 1822) ${ }^{\mathrm{CA}}$

Episyrphus balteatus (De Geer, 1776) ${ }^{\mathrm{CA}}$

Eristalinus aeneus (Scopoli, 1763)

Eristalinus megacephalus (Rossi, 1794)

Eristalinus sepulchralis (Linnaeus, 1758)

Eristalinus taeniops (Wiedemann, 1818)

Eristalis arbustorum (Linnaeus, 1758)

Eristalis horticola (De Geer, 1776)

Eristalis pertinax (Scopoli, 1763)

Eristalis similis (Fallén, 1817) ${ }^{\mathrm{CA}}$

Eristalis tenax (Linnaeus, 1758)

Eumerus amoenus Loew, 1848

Eumerus azabense Ricarte \& Marcos-García sp. nov. ${ }^{\text {CA }}$

Eumerus barbarus (Coquebert, 1804)

Eumerus funeralis Meigen, 1822

Eumerus pulchellus Loew, $1848^{\mathrm{CA}}$

Eumerus pusillus Loew, 1848

Eumerus sabulonum (Fallén, 1817)

Eumerus strigatus (Fallén, 1817)

Eumerus sulcitibius Rondani, 1868

Eupeodes corollae (Fabricius, 1794) ${ }^{\mathrm{CA}}$

Eupeodes flaviceps (Rondani, 1857)

Eupeodes latifasciatus (Macquart, 1829) ${ }^{\mathrm{CA}}$

Eupeodes lucasi (Marcos-García \& Láska, 1983) CA
Eupeodes luniger (Meigen, 1822)

Ferdinandea aurea Rondani, $1844^{\mathrm{CA}}$

Ferdinandea cuprea (Scopoli, 1763) ${ }^{\mathrm{CA}}$

Ferdinandea fumipennis Kassebeer, 1999 CA

Ferdinandea ruficornis (Fabricius, 1775) ${ }^{\mathrm{CA}}$

Helophilus pendulus (Linnaeus, 1758)

Helophilus trivittatus (Fabricius, 1805)

Heringia heringi (Zetterstedt, 1843)

Lejogaster metallina (Fabricius, 1776)

Mallota cimbiciformis (Fallén, 1817) ${ }^{\mathrm{CA}}$

Mallota dusmeti Andréu, 1926 CA

Mallota fuciformis (Fabricius, 1794) ${ }^{\mathrm{CA}}$

Melanogaster aerosa (Loew, 1843)

Melanogaster hirtella Loew, 1843

Melanostoma mellinum (Linnaeus, 1758) $\mathrm{CA}$

Melanostoma scalare (Fabricius, 1794) ${ }^{\mathrm{CA}}$

Meliscaeva auricollis (Meigen, 1822) CA

Merodon aeneus Megerle in Meigen, 1822

Merodon avidus Meigen, 1822

Merodon chalybeus Wiedemann in Meigen, 1822 CA

Merodon clavipes (Fabricius, 1781) ${ }^{\mathrm{CA}}$

Merodon elegans Hurkmans, 1993

Merodon escorialensis Strobl, 1909

Merodon flavus Sack, 1913

Merodon funestus (Fabricius, 1794)

Merodon geniculatus Strobl in Czerny \& Strobl, 1909 CA

Merodon ibericus Vujić in Popović et al. $2015^{\mathrm{CA}}$

Merodon italicus Rondani, $1845^{\mathrm{CA}}$

Merodon obscuritarsis Strobl, 1909 CA

Merodon parietum Wiedemann in Meigen, 1822

Merodon quercetorum Marcos-García, Vujić \& Mengual, 2007

Merodon teruelensis (Van der Goot, 1966)

Merodon trochantericus Costa, 1884

Merodon unicolor Strobl in Czerny \& Strobl, 1909

Microdon devius (Linnaeus, 1761)

Microdon mutabilis (Linnaeus, 1758)

Milesia crabroniformis (Fabricius, 1775)

Milesia semiluctifera (Villers, 1789)

Myathropa florea (Linnaeus, 1758) CA

Myolepta difformis Strobl, 1909 CA

Myolepta dubia (Fabricius, 1805) ${ }^{\mathrm{CA}}$

Myolepta obscura (Becher, 1882) ${ }^{\mathrm{CA}}$

Myolepta vara (Panzer, 1798) ${ }^{\mathrm{CA}}$

Neoascia podagrica (Fabricius, 1775)

Orthonevra frontalis (Loew, 1843)

Orthonevra nobilis (Fallén, 1817)

Paragus albifrons (Fallén, 1817)

Paragus bicolor (Fabricius, 1794) ${ }^{\mathrm{CA}}$

Paragus cinctus Schiner \& Egger, 1853

Paragus flammeus Goeldlin, 1971

Paragus haemorrhous Meigen, $1822^{\mathrm{CA}}$

Paragus pecchiolii Rondani, 1857 CA

Paragus punctulatus (Zetterstedt, 1838)

Paragus quadrifasciatus Meigen, $1822^{\mathrm{CA}}$

Paragus strigatus Meigen, $1822^{\mathrm{CA}}$

Paragus tibialis (Fallén, 1817) ${ }^{\mathrm{CA}}$ 
Appendix 1. Continued.

Paragus vandergooti Marcos-García, 1986 CA Parhelophilus versicolor (Fabricius, 1794) Pelecocera lusitanica (Mik, 1898) ${ }^{\mathrm{CA}}$

Pelecocera tricincta Meigen, 1822 Pipiza festiva Meigen, 1822

Pipizella annulata (Macquart, 1829)

Pipizella viduata (Linnaeus, 1758)

Pipizella virens (Fabricius, 1805)

Platycheirus albimanus (Fabricius, 1781)

Platycheirus angustatus (Zetterstedt, 1843)

Platycheirus fulviventris (Macquart, 1829)

Platycheirus rosarum (Fabricius, 1787)

Platycheirus scutatus (Meigen, 1822)

Platynochaetus setosus (Fabricius, 1794)

Riponnensia splendens (Meigen, 1822)

Scaeva albomaculata (Macquart, 1842)

Scaeva mecogramma (Bigot, 1860)

Scaeva pyrastri (Linnaeus, 1758) ${ }^{\mathrm{CA}}$

Scaeva selenitica (Meigen, 1822)

Sericomyia hispanica Peris, 1962
Sphaerophoria rueppellii Wiedemann, 1830

Sphaerophoria scripta (Linnaeus, 1758) CA

Sphegina limbipennis Strobl, 1909

Sphiximorpha subsessilis (Illiger in Rossi, 1807) CA

Spilomyia digitata (Rondani, 1865) ${ }^{\mathrm{CA}}$

Syritta flaviventris Macquart, 1842

Syritta pipiens (Linnaeus, 1758)

Syrphus ribesii (Linnaeus, 1758)

Syrphus vitripennis Meigen, $1822^{\mathrm{CA}}$

Volucella bombylans (Linnaeus, 1758)

Volucella elegans Loew, $1862^{\mathrm{CA}}$

Volucella inanis (Linnaeus, 1758) CA

Volucella pellucens (Linnaeus, 1758)

Volucella zonaria (Poda, 1761)

Xanthandrus comtus (Harris, 1776)

Xanthogramma marginale (Loew, 1854) CA

Xanthogramma pedissequum (Harris, 1780)

Xylota segnis (Linnaeus, 1758)

Xylota sylvarum (Linnaeus, 1758) 


\begin{tabular}{|c|c|c|c|}
\hline 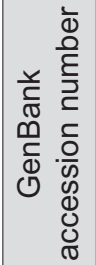 & 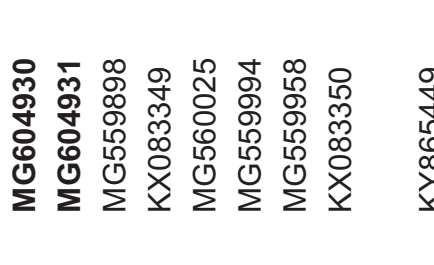 & 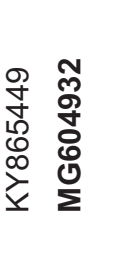 & 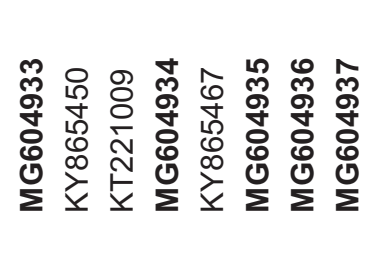 \\
\hline 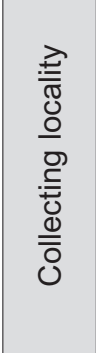 & 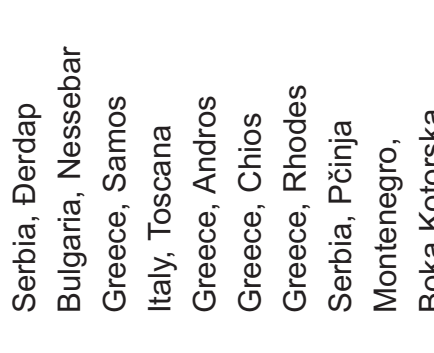 & 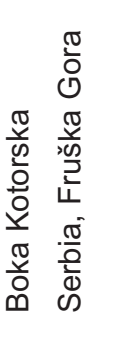 & 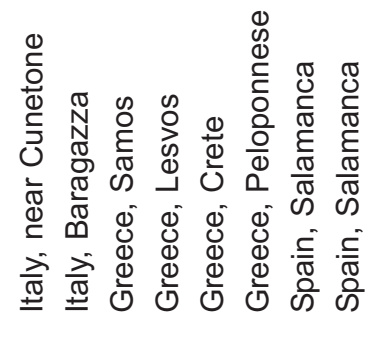 \\
\hline $\begin{array}{l}\text { め) } \\
\text { ஸे }\end{array}$ & 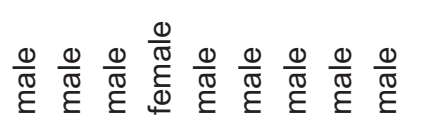 & $\frac{\frac{0}{\pi}}{\mathscr{N}}$ & 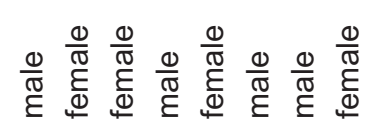 \\
\hline 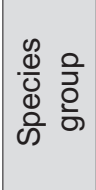 & 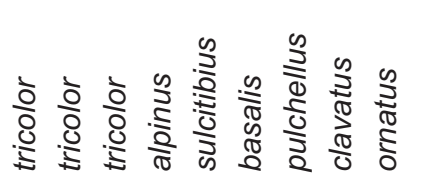 & $\frac{\grave{d}}{\grave{0}}$ & 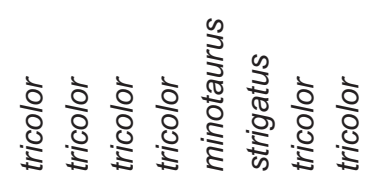 \\
\hline $\begin{array}{l}\frac{\infty}{\infty} \\
\frac{\infty}{\infty} \\
\text { के }\end{array}$ & 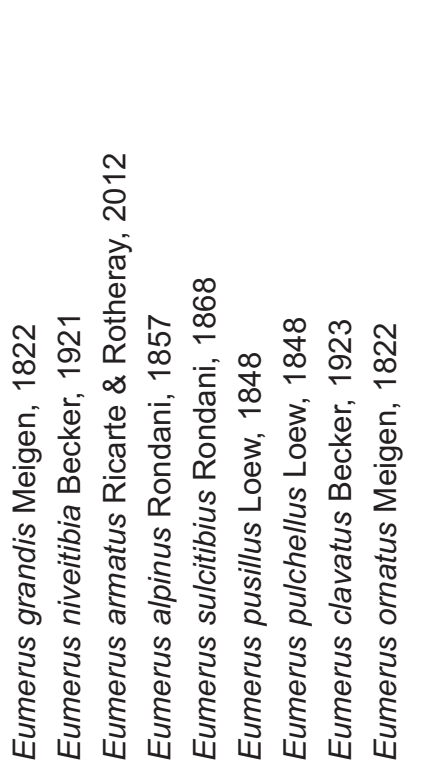 & 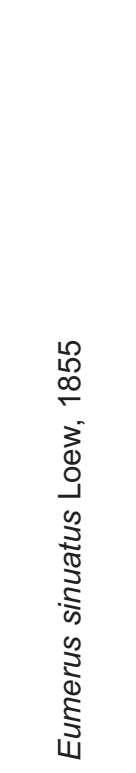 & 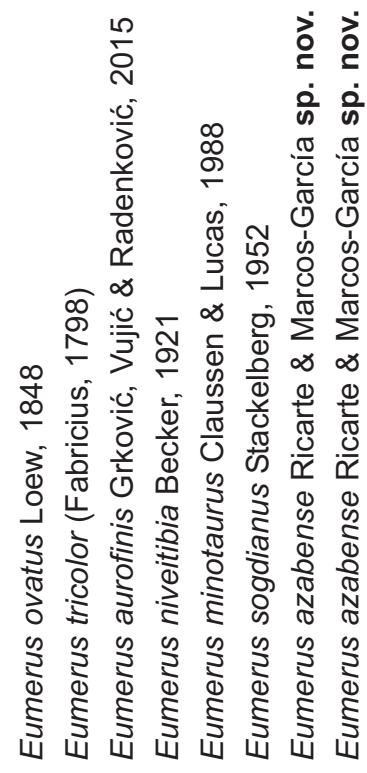 \\
\hline 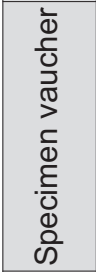 & 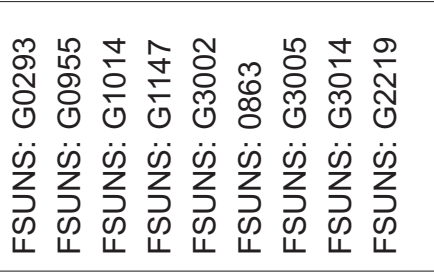 & 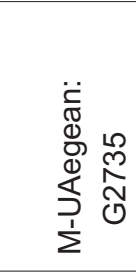 & 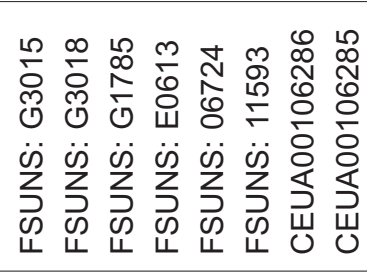 \\
\hline 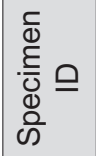 & 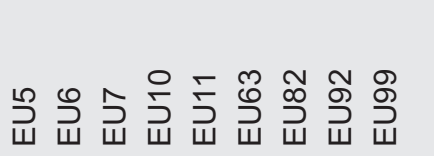 & $\stackrel{\stackrel{N}{5}}{\mathrm{~W}}$ & 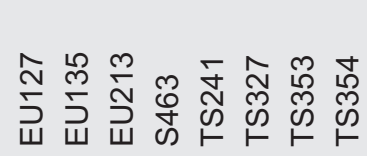 \\
\hline
\end{tabular}

